Article

\title{
Invisible Gold in Pyrite from Epithermal, Banded-Iron-Formation-Hosted, and Sedimentary Gold Deposits: Evidence of Hydrothermal Influence
}

\author{
Yuichi Morishita ${ }^{1,2, * \mathbb{D} \text {, Napoleon Q. Hammond }}{ }^{3}$, Kazunori Momii ${ }^{1}$, Rimi Konagaya ${ }^{1}$, \\ Yuji Sano ${ }^{4} \oplus$, Naoto Takahata ${ }^{4}$ and Hirotomo Ueno ${ }^{5}$ \\ 1 Faculty of Science, Shizuoka University, 836 Ohya, Shizuoka 422-8529, Japan \\ 2 Geological Survey of Japan, AIST, Central 7, Higashi 1-1-1, Tsukuba 305-8567, Japan \\ 3 Department of Geology and Mining, School of Physical and Mineral Sciences, University of Limpopo, \\ Private Bag X1106, Sovenga 0727, South Africa \\ 4 Atmosphere and Ocean Research Institute, University of Tokyo, Chiba 277-8564, Japan \\ 5 Department of Environmental Security Systems, Chiba Institute of Science, Chiba 288-0025, Japan \\ * Correspondence: morishita.yuichi@shizuoka.ac.jp; Tel.: +81-54-238-4792
}

Received: 6 June 2019; Accepted: 12 July 2019; Published: 19 July 2019

\begin{abstract}
Invisible gold" in pyrite is defined as an Au solid solution of the pyrite lattice, sub-microscopic Au nanoparticles (NPs) in the pyrite, or other chemisorption complexes of Au. Because the relationship between the $\mathrm{Au}$ and As concentrations in pyrite could indicate the genesis of the deposit, the purpose of this study is to assess the micro-analytical characteristics of the Au-As relationship in pyrite from epithermal and hydrothermally affected sedimentary Au deposits by secondary ion mass spectrometry. The Au and As concentrations in pyrite vary from 0.04 to $30 \mathrm{ppm}$ and from 1 to 1000 ppm, respectively, in the high-sulfidation Nansatsu-type epithermal deposits; these concentrations are both lower than those of the low-sulfidation epithermal Hishikari deposit. The Au concentrations in pyrrhotite and pyrite reach 6 and 0.3 ppm, respectively, in the Kalahari Goldridge banded-iron-formation-hosted gold deposit, and $\mathrm{Au}$ in pyrrhotite may sometimes exist as NPs, whereas As concentrations in pyrrhotite and pyrite are both low and lie in a narrow range from 6 to $22 \mathrm{ppm}$. Whether Au is present as NPs is important in ore dressing. The Au and As concentrations in pyrite from the Witwatersrand gold field range from 0.02 to $1.1 \mathrm{ppm}$ and from 8 to $4000 \mathrm{ppm}$, respectively. The shape of the pyrite grains might prove to be an indicator of the hydrothermal influence on deposits of sedimentary origin, which implies the genesis of the deposits.
\end{abstract}

Keywords: invisible gold; arsenic; pyrite; epithermal; banded iron formation; sedimentary; hydrothermal; secondary ion mass spectrometry (SIMS)

\section{Introduction}

It has been observed that gold recoveries from ore in many gold mining operations are generally lower than those determined by assay [1]. This is because Au has been found to occur as electrum or native Au and as "invisible gold" that is too small to see by optical microscope. The "invisible gold" comprises sub-microscopic Au nanoparticles (NPs; $<100 \mathrm{~nm},[2-4])$ in minerals, such as sulfides, Au in a solid solution of sulfide crystals, Au in surficial nonautonomous phases [5], and chemisorbed $\mathrm{Au}$ polysulfide complexes [6]. Such Au types are referred to as "invisible gold". It is of great concern whether the "invisible gold" occurs as NPs or as structurally bound in the lattices of the sulfides because the former could be extracted from finely pulverized concentrate, while the latter results in the ore being refractory. Microbeam analytical techniques have been applied to evaluate the presence of $\mathrm{Au}$ in sulfides in Au deposits [7-12]. Morishita and Hammond [13] observed Au peaks corresponding 
to NPs in pyrrhotite from a banded-iron-formation (BIF)-hosted Au deposit in South Africa using secondary ion mass spectrometry (SIMS) depth profiling techniques.

Several studies have shown that there is generally a positive correlation between Au and As concentrations in hand specimens obtained from geochemical Au explorations (e.g., [14]). Pyrite is ubiquitous in most hydrothermal deposits, and several papers have reported that arsenian pyrite is a common host for invisible gold (e.g., [8]). The Au content in pyrite generally increases with an increasing As content [15-17].

Reich et al. [18] have shown that the solubility of Au in arsenian pyrite from Carlin-type and epithermal $\mathrm{Au}$ deposits increases with the As content in the pyrite. They proposed an empirical solubility limit of $\mathrm{Au}$, which defines the boundary between $\mathrm{Au}$ being present as $\mathrm{NPs}\left(\mathrm{Au}^{0}\right)$ or solid solutions $\left(\mathrm{Au}^{+}\right)$in pyrite. Morishita et al. [19] found a positive correlation between $\mathrm{Au}$ and As in the Hishikari pyrite in a microscopic area of $3 \mu \mathrm{m}$. Additionally, Morishita et al. [20] demonstrated that there is a linear correlation between $\mathrm{Au}$ and As concentrations in pyrite from the three ore zones of the high-grade Hishikari deposit.

The purpose of this study is to present the micro-analytical characteristics of the Au-As relationship in pyrite and pyrrhotite (if applicable) from epithermal, BIF-hosted, and sedimentary Au deposits by SIMS for considering the genesis of these ore deposits.

\section{Geological Setting and Mineralogy}

\subsection{High- vs. Low-Sulfidation Epithermal Deposits}

In epithermal systems, deposits with high-sulfidation-state minerals, including enargite, tennantite, and covellite, are commonly referred to as "high-sulfidation" or "acid sulfate" deposits [21,22]. In contrast, "low-sulfidation" deposits (or "adularia-sericite" deposits) of epithermal Au mineralization related to near-neutral $\mathrm{pH}$ and relatively reduced fluids are associated with low-sulfidation-state minerals [22].

\subsection{Epithermal Deposits in Kyushu, Japan}

Kyushu is located at the intersection of the Southwestern Japan Arc and the Ryukyu arc on the eastern margin of the Eurasian plate facing the Philippine Sea Plate. Many epithermal Au deposits of Pliocene to Pleistocene age occur in Late Cenozoic subaerial andesitic to dacitic volcanic rocks in Kyushu, Japan (Figure 1). Kagoshima-ken (a prefecture in Kyushu) is situated in the southernmost part of Kyushu and constitutes two historically fixed districts, the Hokusatsu (Northern Kagoshima) and Nansatsu (Southern Kagoshima) districts (Figure 1). Three high-sulfidation epithermal deposits, the Kasuga, Iwato, and Akeshi deposits, are in the Nansatsu district of Kagoshima-ken and are thus commonly called the Nansatsu-type Au deposits. The low-sulfidation epithermal Hishikari deposit in the Hokusatsu district is about $90 \mathrm{~km}$ north of the Nansatsu-type Au deposits (Figure 1). 


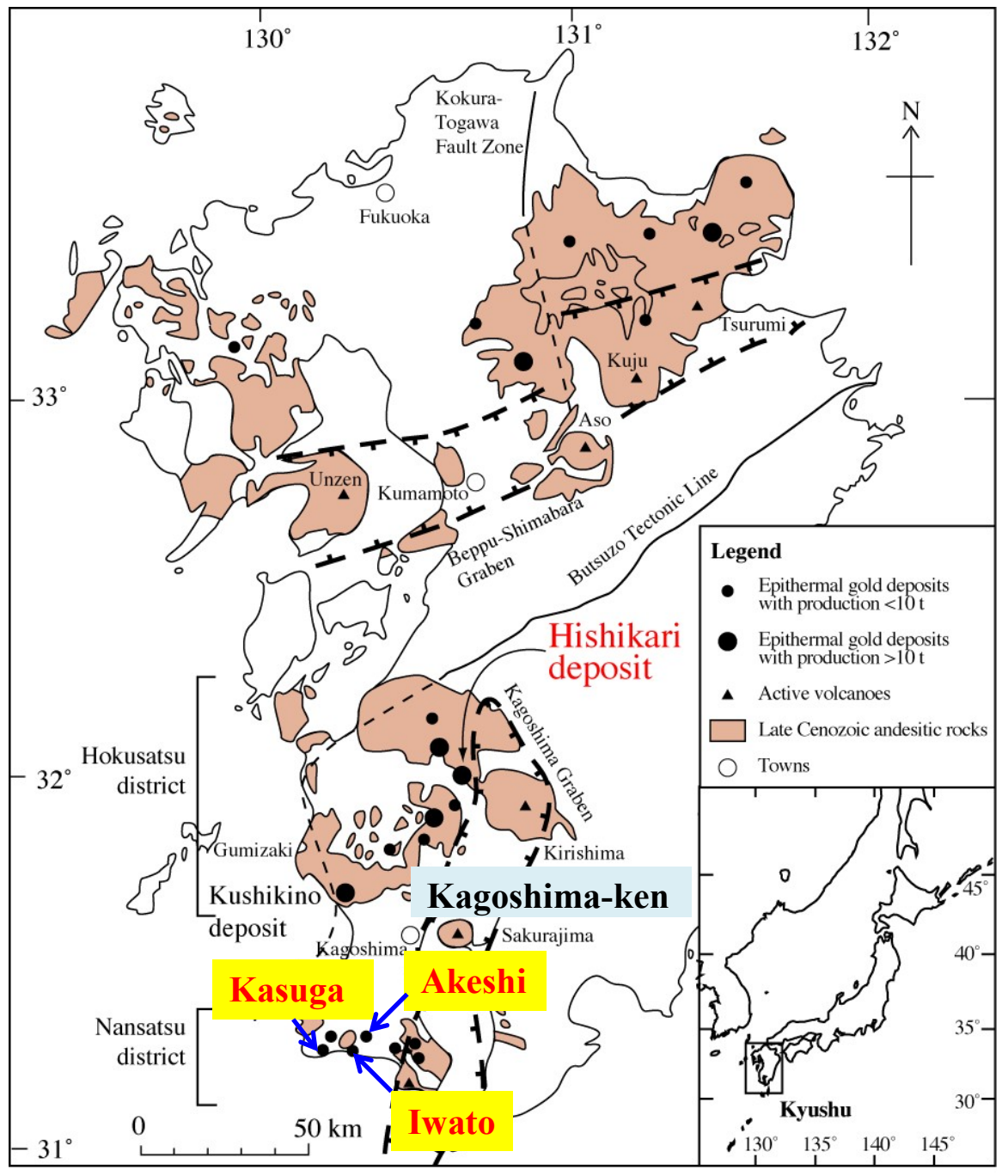

Figure 1. Epithermal gold deposits in Kyushu in Southwestern Japan [23,24]. The location of the Kasuga, Iwato, and Akeshi deposits are shown in addition to the Hishikari deposit.

\subsection{High-Sulfidation Nansatsu-Type Au Deposits in the Nansatsu District of Kagoshima-ken}

Calc-alkaline volcanism in Kagoshima-ken has moved eastward at an average speed of $0.6 \mathrm{~cm} / \mathrm{year}$ from $8 \mathrm{Ma}$ to date $[25,26]$. The eastward shift of the volcanic front may be due to a progressive steepening of the west-dipping subduction slab [26]. As hydrothermal activity has followed the volcanism, the location of Au mineralization has also moved eastward. Among the three Nansatsu-type Au deposits, the westernmost Kasuga deposit formed circa $5 \mathrm{Ma}$, and the intermediate Iwato and easternmost Akeshi deposits (younger than $4 \mathrm{Ma}$ ) have formed in turn in the Nansatsu district of Kagoshima-ken (Figure 1) [26]. The present-day active volcanic front occurs approximately $30 \mathrm{~km}$ east of the Nansatsu deposits. The Nansatsu district is underlain by sedimentary rocks of the Cretaceous Shimanto Supergroup (primarily of the Kawanabe Group). Kaolinite and its higher-temperature polymorph, dickite, are common in the Nansatsu deposits [27].

\subsubsection{Kasuga Deposit}

The Kasuga main ore body consists of a silicified zone extending $500 \mathrm{~m} \mathrm{E}-\mathrm{W}$ and $100 \mathrm{~m} \mathrm{~N}-\mathrm{S}$, with a thickness of approximately $80 \mathrm{~m}$. The silica body is enveloped by an argillic zone that consists of an inner dickite (alunite-pyrophyllite) zone and an outer illite-chlorite zone. The average Au content of the silicified rock ranges from 2 to $3 \mathrm{~g} / \mathrm{t}$ [28]. The principal ore minerals in the deposit are enargite and 
native gold. Pyrite is ubiquitous throughout the ore body. Several quartz veinlet systems are oriented radially with respect to a basement depression in the vicinity of Kasuga [27]. The mineral paragenesis of the Kasuga deposit is given in Table 1.

Table 1. General description of the studied Au deposits.

\begin{tabular}{|c|c|c|c|}
\hline Type & Sub-Type/Region & Name & Mineral Assemblage \\
\hline Epithermal & $\begin{array}{l}\text { high-sulfidation } \\
\text { Nansatsu-type }\end{array}$ & Kasuga & $\begin{array}{l}\text { quartz, enargite, pyrite, native gold, } \\
\text { alunite, kaolinite, dickite, covelline, } \\
\text { native sulfur, goethite }[27,28]\end{array}$ \\
\hline Epithermal & $\begin{array}{l}\text { high-sulfidation } \\
\text { Nansatsu-type }\end{array}$ & Iwato & $\begin{array}{l}\text { quartz, pyrite, native gold, alunite, } \\
\text { kaolinite, dickite, goethite [28] }\end{array}$ \\
\hline Epithermal & $\begin{array}{l}\text { high-sulfidation } \\
\text { Nansatsu-type }\end{array}$ & Akeshi & $\begin{array}{l}\text { quartz, luzonite, pyrite, native gold, } \\
\text { covelline, alunite, native sulfur, } \\
\text { kaolinite, dickite, smectite, scorodite, } \\
\text { goethite [28] }\end{array}$ \\
\hline Epithermal & low-sulfidation vein-type & Hishikari & $\begin{array}{l}\text { quartz, adularia, smectite, pyrite, } \\
\text { marcasite, electrum, } \\
\text { naumannite-aguilarite, pyrargyrite, } \\
\text { chalcopyrite [29] }\end{array}$ \\
\hline $\begin{array}{l}\text { BIF-hosted } \\
\text { hydrothermal }\end{array}$ & Kraaipan greenstone belt & Kalahari Goldridge & $\begin{array}{l}\text { quartz, siderite, ankerite, calcite, } \\
\text { pyrite, pyrrhotite, stilpnomelane, } \\
\text { chlorite, magnetite, epidote, } \\
\text { plagioclase [30] }\end{array}$ \\
\hline $\begin{array}{l}\text { Sedimentary \& } \\
\text { hydrothermal }\end{array}$ & $\begin{array}{c}\text { auriferous } \\
\text { palaeoplacer/Witwatersrand } \\
\text { basin }\end{array}$ & South Deep & quartz, pyrite, native gold \\
\hline $\begin{array}{l}\text { Sedimentary \& } \\
\text { hydrothermal }\end{array}$ & $\begin{array}{c}\text { auriferous } \\
\text { palaeoplacer/Witwatersrand } \\
\text { basin }\end{array}$ & KDC West & quartz, pyrite, native gold \\
\hline
\end{tabular}

BIF: banded iron formation. KDC: Kloof-Driefontein Complex.

\subsubsection{Iwato Deposit}

The Iwato silicified zone extends more than $1200 \mathrm{~m}$ E-W and approximately $200 \mathrm{~m}$ N-S, with a thickness of approximately $100 \mathrm{~m}$. Three groups of ore bodies occur within the silicified zone; from east to west, these are the Maruyama ore bodies, the Arabira ore bodies, and the Iwashita ore body. Although the silicified zone continues further to the southwest, minable Au has not been found there. Most of the silicified rocks there contain more than $0.2 \mathrm{~g} / \mathrm{t} \mathrm{Au}$. The high-grade zone (above $4 \mathrm{~g} / \mathrm{t}$ ) often has a mushroom shape [28]. The mineral paragenesis of the Iwato deposit is given in Table 1.

\subsubsection{Akeshi Deposit}

A silicified zone $(300 \mathrm{~m} \times 200 \mathrm{~m}$, with a thickness of approximately $150 \mathrm{~m})$ contains high-grade zones consisting of gray or milky white quartz. The No. 1 ore body $(100 \mathrm{~m} \mathrm{NE}-\mathrm{SW}$ with a width of $40 \mathrm{~m}$ ) plunges SW at an angle of $60^{\circ}$ from the surface (75 m above sea level) to $75 \mathrm{~m}$ below sea level. The Akeshi mineralization is the youngest of the three Nansatsu deposits. The Kasuga and Iwato ore bodies formed before deposition of the Nansatsu Middle Volcanics, which host the Akeshi deposit [27]. Primary Au is closely associated with luzonite and pyrite [31]. The mineral paragenesis of the Akeshi deposit is given in Table 1.

\subsection{Low-Sulfidation Au Deposits in the Hokusatsu District of Kagoshima-ken}

Au mineralization in the Hokusatsu district (Figure 1) is typical of low-sulfidation quartz veins with adularia and calcite. The epithermal Au deposits, including the Hishikari deposit and the Kushikino deposit [32], which is the second largest in Kyushu, have formed from the Pliocene to Pleistocene in the Hokusatsu district. 


\section{Hishikari Deposit}

The Hishikari deposit, located in the southern part of Kyushu, is the largest Au deposit in Japan (Figure 1). The Hishikari deposit is a low-sulfidation epithermal deposit and is quite famous for its high-grade ore. The Hishikari deposit consists of the Sanjin, Honko, and Yamada ore zones. The Sanjin and Honko ore zones occur in the Cretaceous basement sedimentary rocks of the Lower Shimanto Group. In contrast, veins in the Yamada ore zone occur in Pleistocene andesitic rocks that overlie the basement sedimentary rocks. The mineralization of the Hishikari deposit began at $1.15 \mathrm{Ma}$ and ended by $0.60 \mathrm{Ma}$ [24]. The Hishikari veins consist mainly of quartz, adularia, and smectite, and the most abundant metallic mineral is pyrite. The mineral paragenesis of the Hishikari deposit is given in Table 1. The occurrence of As-bearing minerals, such as arsenopyrite, is not known.

\subsection{BIF-Hosted Deposit}

\section{Kalahari Goldridge Deposit}

The Kalahari Goldridge deposit is a typical lode-gold deposit hosted by BIF in the Archaean Kraaipan Greenstone Belt in the Northwestern Province of South Africa (Figure 2). The genesis of the deposit has been documented [30,33,34]. The Kalahari Goldridge deposit is hosted in a strata-bound iron-formation (3.41 Ga) [35]. It comprises the D zone, A zone, Watertank, and Windmill ore bodies. The entire ore body stretches along a strike length of approximately $6.5 \mathrm{~km} \mathrm{~N}-\mathrm{S}$. The ore zone is characterized by meta-sedimentary rocks.

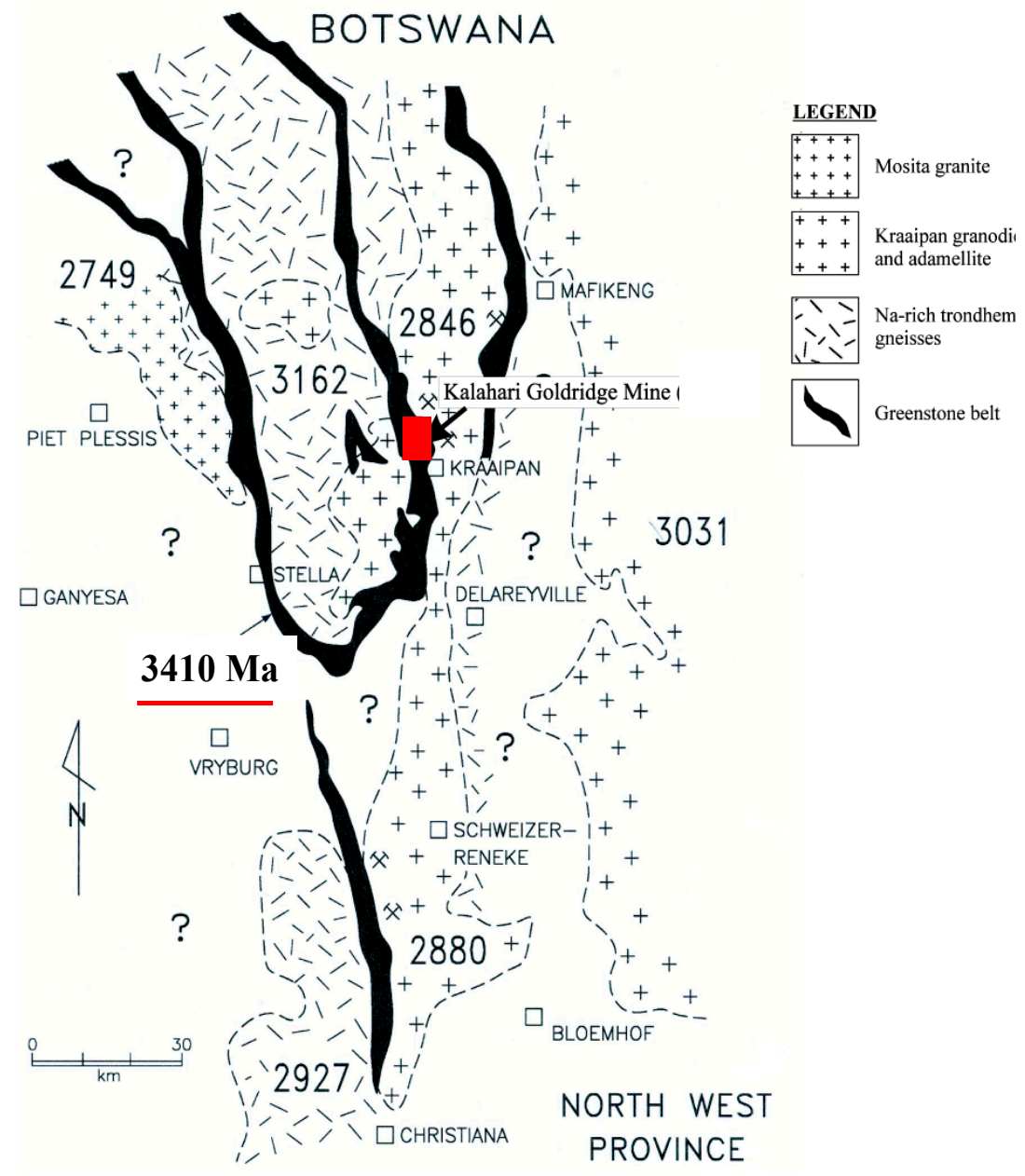

Figure 2. Simplified geologic map of the Kraaipan terrane [35], showing the locality of the Kalahari mine. Numbers indicate approximate ages (Ma) of BIFs and related rocks. 
Principal mineralogy at Kalahari Goldridge includes silicates (chlorite, stilpnomelane, minnesotaite, and muscovite), carbonates (siderite, ankerite-dolomite series, and calcite), and opaque minerals (magnetite, pyrite, pyrrhotite, and chalcopyrite) [30,33,34]. The Kalahari Goldridge deposit hosted by BIF was formed under relatively reduced circumstances, and pyrite and pyrrhotite were found in the deposit. The mineral paragenesis of the Kalahari Goldridge deposit is given in Table 1.

Mineralogical studies at the Kalahari Goldridge deposit have revealed that despite the relatively high assay values found in bulk ores, particularly in pyrrhotite-rich areas, samples showed minor or no visible $\mathrm{Au}$ grains during microscopic observations [33,34]. These observations suggest that $\mathrm{Au}$ likely occurs at submicroscopic levels or is structurally bound in the lattices of the sulfides in these samples. The presence of submicroscopic Au in sulfides has been a major contributor to refractory $\mathrm{Au}$ ores, which presents great difficulty in using conventional extractive metallurgy to extract the $\mathrm{Au}$ from these ores. At the Kalahari Goldridge mine, Au recovery stands at $80 \%$, indicating the possible occurrence of submicroscopic $\mathrm{Au}$ in the ores at the deposit.

\subsection{Sedimentary Au Deposits (Witwatersrand Au Fields)}

The Witwatersrand sedimentary basin is situated in the central part of the Kaapvaal Craton of South Africa. This basin consists of a $6000 \mathrm{~m}$-thick layer of clastic sedimentary rocks, the Archaean Witwatersrand Supergroup, and yields auriferous and uraniferous quartz-pebble conglomerates (reefs) [36]. The Witwatersrand Supergroup, which is divided into the lower West Rand and upper Central Rand Groups, has contributed more than one-third of the world's total historic production. The bottom of the Witwatersrand Supergroup has been dated to 2970 Ma [37], whereas the top has been dated to $2714 \mathrm{Ma}$ [38]. The reefs are considered to represent vast fluvial fans. The Au is mostly of detrital origin, deposited syngenetically with the conglomerates [39]. Pyrite is ubiquitous in the Witwatersrand Au-bearing conglomerates [37].

The initial source of Au was the surrounding Archaean granite-greenstone terrain of the Kaapvaal Craton [36]. The Au occurred in association with pyrite, carbon, and uranium, and most of it has been subsequently modified during later hydrothermal activity [36]. Although debate is ongoing as to whether the genesis of the Witwatersrand Au deposits can be attributed to a paleo-placer source or a hydrothermal source, the modified placer process (a combination of the two sources) is thought to be more plausible [40].

\subsubsection{South Deep Deposit}

The South Deep Au mine in the West Rand Goldfield lies at the northwestern edge of the Witwatersrand Basin at latitude $26^{\circ} 25^{\prime} \mathrm{S}$, longitude $27^{\circ} 40^{\prime} \mathrm{E}$ (Figure 3). The mining target reefs are both the Ventersdorp Contact Reef (VCR) and the Upper Elsburg formation conglomerates [36]. The VCR overlies footwall lithologies of the Turffontein Subgroup in the western part of the mining area. The Upper Elsburg reefs consist of multiple stacked reefs. The Upper Elsburg reef is well-understood thanks to information integrated from surface drilling, three-dimensional (3D) surface seismic surveys, and underground long inclined drillings [36]. Au production amounted to $4885 \mathrm{~kg}$ in 2018 [41].

\subsubsection{KDC West Deposit}

The Kloof-Driefontein Complex (KDC) is situated in the Far West Rand Goldfields at latitude $26^{\circ} 24^{\prime} \mathrm{S}$ and longitude $27^{\circ} 30^{\prime}$ E (Figure 3). The Kloof Au Mine (KDC East) and Driefontein Au Mine (KDC West) are situated in the mining area. Au mineralization occurs within quartz-pebble conglomerate reefs, which are developed above unconformable surfaces near the basin margin. The mining target reefs are the Carbon Leader Reef (CL), Ventersdorp Contact Reef (VCR), and Middelvlei Reef (MR). The CL represents most of the current mineral reserves in the KDC West. It varies in thickness from a mere carbon streak to a multiple-band conglomerate of about $200 \mathrm{~cm}$ thick [39]. The deepest operating level is $3420 \mathrm{~m}$ below the surface (50 Level at 5 Shaft) in the KDC West. The current 
mineral reserves will possibly remain operating until 2039 [42]. In 2018, the underground production from the KDC West amounted to $8952 \mathrm{~kg}$ [43].

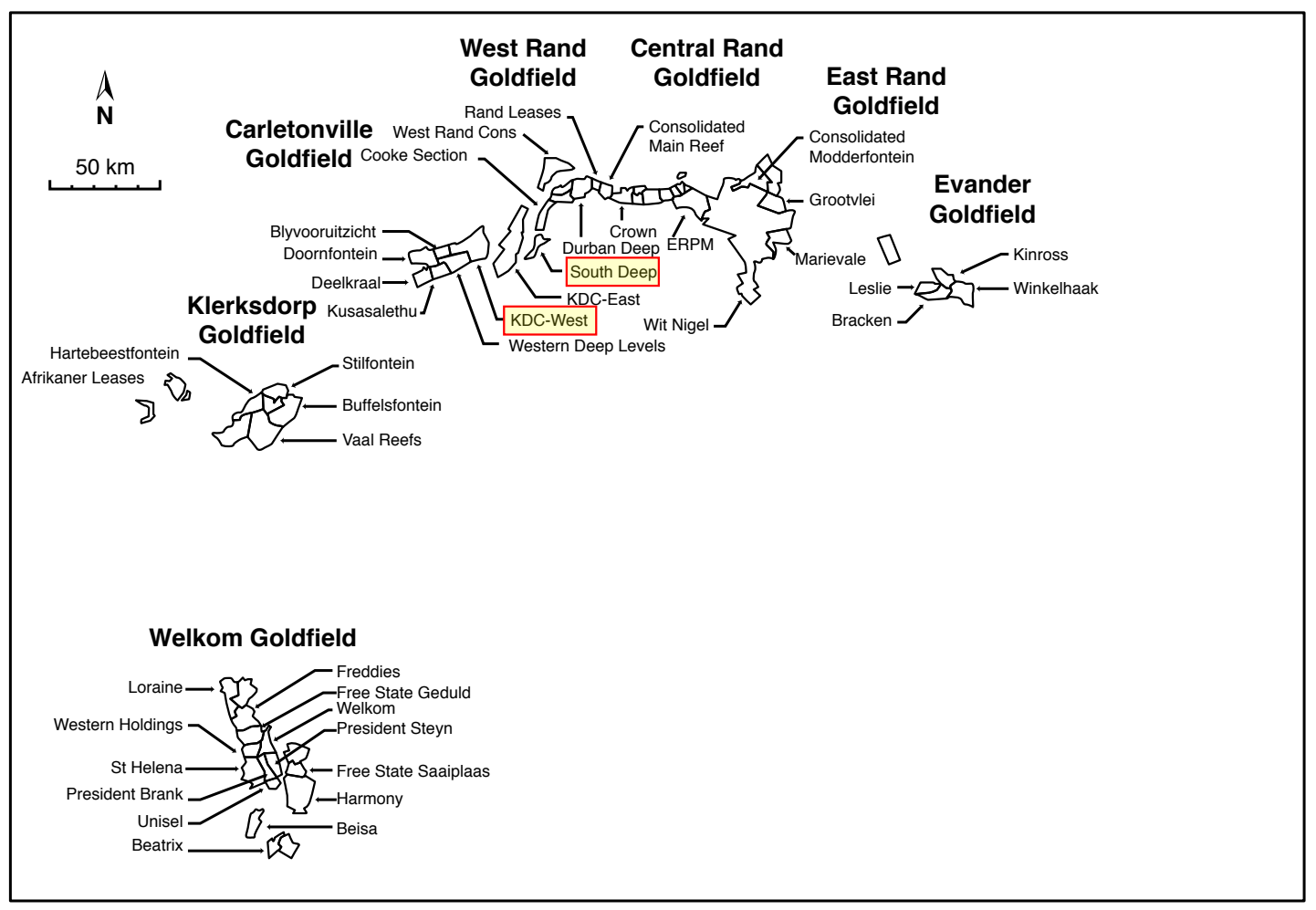

Figure 3. Location of the Witwatersrand gold mines [44], showing the localities of the South Deep and KDC (Kloof-Driefontein Complex) West mines.

\section{Materials and Methods}

\subsection{Materials}

Pyrite is the most abundant sulfide and is ubiquitous throughout the high-sulfidation epithermal deposits in the Nansatsu district (the Kasuga, Iwato, and Akeshi deposits) and the low-sulfidation epithermal Hishikari deposit (Table 1). Pyrite samples from the Kasuga deposit were collected from drill core 11MANU-1, which was drilled vertically from the $100 \mathrm{~mL}$ (100 m above sea level) bench of the mine [45]. The Iwato pyrite samples were from the $150 \mathrm{~mL}$ bench of the Maruyama open pit. The Akeshi pyrite samples containing covelline and native sulfur were from the $-50 \mathrm{~mL}$ (underground) bench of the No. 1 ore body. Pyrite and pyrrhotite from the Kalahari Goldridge deposit, as well as pyrite from the South Deep and KDC West deposits in the Witwatersrand Basin, South Africa, were sampled for analysis.

The size and shape of the analyzed minerals are described in Table 2. Because the size of a mineral grain is measured on a thin section, it roughly represents the actual 3D substance. Table 2 gives the lengths of the major and minor axes of the grains. The roundness [46], which indicates the degree of abrasion, is another important factor in describing mineral grains in sedimentary-origin Au deposits. The mineral grains assessed in this study were divided into four categories based on their roundness: Crystalline, angular, subangular, and rounded, in order of increasing roundness. The crystalline grains retain their original crystal shapes. 
Table 2. Results of secondary ion mass spectrometry (SIMS) analysis.

\begin{tabular}{|c|c|c|c|c|c|c|c|c|}
\hline Deposit & Sample Name & Locality & Analysis Spot & Analysis No. & Mineral & $\mathrm{Au}(\mathrm{ppm})$ & As (ppm) & Analysis Position-Size-Roundness \\
\hline Kasuga & S113 & $19.6 \mathrm{~m}$ depth & N1 & Au5*246.adp & pyrite & 0.06 & 44 & core-260 $\mu \mathrm{m} \times 320 \mu \mathrm{m}$-subangular \\
\hline Kasuga & S113 & $19.6 \mathrm{~m}$ & N11 & Au5*256.adp & pyrite & 0.04 & 2 & core-the same grain as above \\
\hline Kasuga & $\mathrm{S} 113$ & $19.6 \mathrm{~m}$ & N2 & Au5*247.adp & pyrite & 0.09 & 6 & core-120 $\mu \mathrm{m} \times 130 \mu \mathrm{m}$-subangular \\
\hline Kasuga & S113 & $19.6 \mathrm{~m}$ & N3 & $\mathrm{Au} 5 * 248 . \mathrm{adp}$ & pyrite & 0.05 & 44 & rim-the same grain as above \\
\hline Kasuga & S113 & $19.6 \mathrm{~m}$ & N4 & Au5*249.adp & pyrite & 0.10 & 2 & rim-the same grain as above \\
\hline Kasuga & S113 & $20.5 \mathrm{~m}$ & N6 & Au5*251.adp & pyrite & 0.24 & 3 & core- $400 \mu \mathrm{m} \times 400 \mu \mathrm{m}$-subangular \\
\hline Kasuga & S113 & $20.5 \mathrm{~m}$ & N7 & $\mathrm{Au} 5^{*} 252 . \mathrm{adp}$ & pyrite & 0.17 & 3 & rim-50 $\mu \mathrm{m} \times 60 \mu \mathrm{m}$-subangular \\
\hline Kasuga & S113 & $90.2 \mathrm{~m}$ & N8 & Au5*253.adp & pyrite & 0.17 & 64 & core-200 $\mu \mathrm{m} \times 300 \mu \mathrm{m}$-subangular \\
\hline Kasuga & S113 & $138.3 \mathrm{~m}$ & N10 & $\mathrm{Au} 5^{*} 255$.adp & pyrite & 0.14 & 1 & core-100 $\mu \mathrm{m} \times 250 \mu \mathrm{m}$-subangular \\
\hline Kasuga & $\mathrm{S} 113$ & $19.6 \mathrm{~m}$ & N13 & Au5*258.adp & pyrite & 0.09 & 17 & core-50 $\mu \mathrm{m} \times 100 \mu \mathrm{m}$-subangular \\
\hline Kasuga & S113 & $19.6 \mathrm{~m}$ & N14 & $\mathrm{Au} 5 * 259$.adp & pyrite & 0.06 & 2 & core-120 $\mu \mathrm{m} \times 140 \mu \mathrm{m}$-angular \\
\hline Kasuga & S113 & $19.6 \mathrm{~m}$ & N15 & Au5*260.adp & pyrite & 23.58 & 176 & core-20 $\mu \mathrm{m} \times 40 \mu \mathrm{m}$-subangular \\
\hline Kasuga & S113 & $19.6 \mathrm{~m}$ & N16 & Au5*261.adp & pyrite & 22.40 & 395 & core-20 $\mu \mathrm{m} \times 30 \mu \mathrm{m}$-subangular \\
\hline Iwato & S176 & Maruyama & Py1a & Au5a*285.adp & pyrite & 1.59 & 24 & rim-150 $\mu \mathrm{m} \times 200 \mu \mathrm{m}$-mosaic \\
\hline Iwato & S176 & Maruyama & Py1b & Au5a*287.adp & pyrite & 2.84 & 14 & rim-the same grain as above \\
\hline Iwato & S176 & Maruyama & Py4a & Au5a*286.adp & pyrite & 0.16 & 19 & core-100 $\mu \mathrm{m} \times 200 \mu \mathrm{m}$-mosaic \\
\hline Iwato & S176 & Maruyama & Рy3a & Au5a*288.adp & pyrite & 0.25 & 43 & core-30 $\mu \mathrm{m} \times 40 \mu \mathrm{m}$-subangular \\
\hline Akeshi & S174 & No.1 ore body & $\# 2$ & Au5a*290.adp & pyrite & 0.17 & 847 & rim-50 $\mu \mathrm{m} \times 70 \mu \mathrm{m}$-crystalline \\
\hline Akeshi & S174 & No.1 ore body & \#6 & Au5a*294.adp & pyrite & 0.04 & 420 & rim-20 $\mu \mathrm{m} \times 50 \mu \mathrm{m}$-subangular \\
\hline Akeshi & S174 & No.1 ore body & \#3 & Au5a*295.adp & pyrite & 33.53 & 703 & rim-30 $\mu \mathrm{m} \times 60 \mu \mathrm{m}$-irregular \\
\hline Akeshi & S174 & No.1 ore body & $\# 7$ & Au5a*296.adp & pyrite & 0.07 & 56 & core-50 $\mu \mathrm{m} \times 90 \mu \mathrm{m}$-subangular \\
\hline Akeshi & S174 & No.1 ore body & $\# 8$ & Au5a*297.adp & pyrite & 0.54 & 111 & core-50 $\mu \mathrm{m} \times 60 \mu \mathrm{m}$-crystalline \\
\hline Kalahari & S79 & D zone $118 / 21 / 11 \mathrm{~A}$ & \#3 & $\mathrm{Au} 4 * 2 . \mathrm{adp}$ & pyrite & 0.01 & 22 & core-500 $\mu \mathrm{m} \times 1000 \mu \mathrm{m}$-subangular \\
\hline Kalahari & S82 & D zone $118 / 21 / 15 \mathrm{~A}$ & $\mathrm{~K} 2 \_2$ & 0703_8\#1 & pyrite & 0.32 & 17 & core- $80 \mu \mathrm{m} \times 100 \mu \mathrm{m}$-subangular \\
\hline Kalahari & S82 & D zone $118 / 21 / 15 \mathrm{~A}$ & \#31 Po & Au5aa*31.adp & Pyrrhotite & 0.53 & 8 & core-250 $\mu \mathrm{m} \times 250 \mu \mathrm{m}$-mosaic \\
\hline Kalahari & S82 & D zone $118 / 21 / 15 \mathrm{~A}$ & \#32 Po & Au5aa*32.adp & Pyrrhotite & 0.80 & 12 & core-the same grain as above \\
\hline Kalahari & $\mathrm{S} 82$ & D zone $118 / 21 / 15 \mathrm{~A}$ & \#23 Po & Au5aa*33.adp & Pyrrhotite & 0.86 & 6 & core-the same grain as above \\
\hline Kalahari & $\mathrm{S} 82$ & D zone $118 / 21 / 15 \mathrm{~A}$ & K1_3 & 0703_2 \#1 & Pyrrhotite & 0.87 & 19 & core-the same grain as above \\
\hline Kalahari & S82 & D zone $118 / 21 / 15 \mathrm{~A}$ & K1_4 & 0703_3 \#1 & Pyrrhotite & 0.25 & 17 & core-the same grain as above \\
\hline Kalahari & S82 & D zone $118 / 21 / 15 \mathrm{~A}$ & K1_5 & 0703_4 \#1 & Pyrrhotite & 0.07 & 13 & core-the same grain as above \\
\hline Kalahari & $\mathrm{S} 82$ & D zone $118 / 21 / 15 \mathrm{~A}$ & K1_6 & 0703_5 \#1 & Pyrrhotite & 0.01 & 8 & core-50 $\mu \mathrm{m} \times 50 \mu \mathrm{m}$-mosaic \\
\hline Kalahari & S82 & D zone $118 / 21 / 15 \mathrm{~A}$ & K2_1 & 0703_7 \#1 & Pyrrhotite & 0.01 & 8 & core-200 $\mu \mathrm{m} \times 250 \mu \mathrm{m}$-rounded \\
\hline Kalahari & S82 & D zone $118 / 21 / 15 \mathrm{~A}$ & $\mathrm{~K} 2 \_3$ & 0703_9\#1 & Pyrrhotite & 0.01 & 8 & core-100 $\mu \mathrm{m} \times 100 \mu \mathrm{m}$-mosaic \\
\hline
\end{tabular}


Table 2. Cont

\begin{tabular}{|c|c|c|c|c|c|c|c|c|}
\hline Deposit & Sample Name & Locality & Analysis Spot & Analysis No. & Mineral & $\mathrm{Au}(\mathrm{ppm})$ & As (ppm) & Analysis Position-Size-Roundness \\
\hline South Deep & S196 & MIT in Upper Elsburgs & S11 & 0702_4 \#1 & pyrite & 0.04 & 21 & core- $350 \mu \mathrm{m} \times 450 \mu \mathrm{m}$-rounded \\
\hline South Deep & S196 & MIT in Upper Elsburgs & S12 & $0702 \_5 \# 1$ & pyrite & 0.02 & 19 & rim-the same grain as above \\
\hline South Deep & S196 & MIT in Upper Elsburgs & $\mathrm{S} 13$ & 0702_6\#1 & pyrite & 0.03 & 103 & core-200 $\mu \mathrm{m} \times 400 \mu \mathrm{m}$-subangular \\
\hline South Deep & S196 & MIT in Upper Elsburgs & S14 & $07027 \# 1$ & pyrite & 0.03 & 827 & rim-the same grain as above \\
\hline South Deep & S196 & MIT in Upper Elsburgs & S15 & $0702 \_8 \# 1$ & pyrite & 0.22 & 1988 & core-200 $\mu \mathrm{m} \times 270 \mu \mathrm{m}$-angular \\
\hline South Deep & S196 & MIT in Upper Elsburgs & S16 & 0702_9\#1 & pyrite & 0.34 & 2297 & rim-the same grain as above \\
\hline South Deep & S196 & MIT in Upper Elsburgs & S26 & $1026 \_6 \# 1$ & pyrite & 0.14 & 2789 & rim-the same grain as above \\
\hline South Deep & S196 & MIT in Upper Elsburgs & S27 & 1026_7\#1 & pyrite & 1.09 & 4042 & core-the same grain as above \\
\hline South Deep & S196 & MIT in Upper Elsburgs & S21 & 1026_1 \#1 & pyrite & 0.05 & 8 & core-300 $\mu \mathrm{m} \times 600 \mu \mathrm{m}$-round \\
\hline South Deep & S196 & MIT in Upper Elsburgs & S23 & 1026_3 \#1 & pyrite & 0.04 & 49 & core-the same grain as above \\
\hline South Deep & S196 & MIT in Upper Elsburgs & S24 & $1026 \_4$ \#1 & pyrite & 0.05 & 102 & core- $200 \mu \mathrm{m} \times 300 \mu \mathrm{m}$-subangular \\
\hline South Deep & S196 & MIT in Upper Elsburgs & S25 & $1026 \_5 \# 1$ & pyrite & 0.04 & 177 & rim-the same grain as above \\
\hline South Deep & S196 & MIT in Upper Elsburgs & S28 & 1026_8\#1 & pyrite & 0.03 & 33 & rim-600 $\mu \mathrm{m} \times 650 \mu \mathrm{m}$-rounded \\
\hline South Deep & S196 & MIT in Upper Elsburgs & S29 & 1026_9\#1 & pyrite & 0.02 & 19 & core-the same grain as above \\
\hline South Deep & S196 & MIT in Upper Elsburgs & S30 & $1026 \_10 \# 1$ & pyrite & 0.08 & 59 & core-50 $\mu \mathrm{m} \times 80 \mu \mathrm{m}$-subangular \\
\hline KDC West & S197 & 2B (Carbon Leader) & D3 & Au5aa*1.adp & pyrite & 0.12 & 1546 & core-250 $\mu \mathrm{m} \times 350 \mu \mathrm{m}$-subangular \\
\hline KDC West & S197 & 2B (Carbon Leader) & D1 & Au5aa*3.adp & pyrite & 0.22 & 1238 & rim-250 $\mu \mathrm{m} \times 350 \mu \mathrm{m}$-subangular \\
\hline KDC West & S197 & 2B (Carbon Leader) & $\mathrm{D} 2$ & Au5aa*2.adp & pyrite & 0.62 & 200 & rim-300 $\mu \mathrm{m} \times 300 \mu \mathrm{m}$-rounded \\
\hline KDC West & S197 & 2B (Carbon Leader) & D14 & 0702_3\#1 & pyrite & 0.63 & 153 & rim-the same grain as above \\
\hline KDC West & S197 & 2B (Carbon Leader) & D12 & 0702_1 \#1 & pyrite & 0.04 & 22 & core- $150 \mu \mathrm{m} \times 200 \mu \mathrm{m}$-rounded \\
\hline
\end{tabular}

\#1: determined by Atmosphere and Ocean Research Institute (AORI) NanoSIMS at the University of Tokyo. 


\subsection{Analytical Methods}

The pyrite and pyrrhotite were quantitatively analyzed ( $3 \mu \mathrm{m} \times 3 \mu \mathrm{m}$ field) using a Cameca IMS 1270 spectrometer at the Geological Survey of Japan (GSJ), National Institute of Advanced Industrial Science and Technology (AIST). A defocused $\mathrm{Cs}^{+}$primary ion beam was restricted to $20 \mu \mathrm{m}$ in diameter by a circular aperture to obtain a homogeneous primary beam of approximately $100 \mathrm{pA}$. Sputtered negative secondary ions with an accelerating voltage of $-10 \mathrm{kV}$ were extracted from the carbon-coated polished sample surface and were detected using a total impact energy of $20 \mathrm{kV}$ (primary accelerating voltage of $+10 \mathrm{kV}$ and secondary extraction voltage of $-10 \mathrm{kV}$ ). The secondary ${ }^{197} \mathrm{Au}^{-}$and ${ }^{75} \mathrm{As}^{-}$ions (both are monoisotopic), as well as the matrix ${ }^{34} \mathrm{~S}^{-}$used as an internal reference, were detected using an electron multiplier (EM). A rectangular field aperture of $300 \mu \mathrm{m} \times 300 \mu \mathrm{m}$ was introduced into the secondary ion optics, limiting the analyzed area on the sample surface to a central square measuring $3 \mu \mathrm{m} \times 3 \mu \mathrm{m}$ to avoid the crater edge effect. The centering of the primary beam was ascertained each time by looking at the beam position in the field aperture of $2 \mathrm{~mm} \times 2 \mathrm{~mm}$ (primary beam of $20 \mu \mathrm{m}$ in diameter). An electron flood gun was used on the sample surface for the purpose of charge compensation to achieve better stability of the secondary ions. The isobaric interference of ${ }^{133} \mathrm{Cs}^{32} \mathrm{~S}_{2}$ is clearly separated from ${ }^{197} \mathrm{Au}(M / \Delta M=1728)$ by a mass-resolving power of 3300 without energy filtering [20]. Measurements at 3, 5, and $10 \mathrm{~s}$ for ${ }^{34} \mathrm{~S}^{-},{ }^{75} \mathrm{As}^{-}$, and ${ }^{197} \mathrm{Au}^{-}$ions, respectively, were allocated for each measurement cycle. It takes $24 \mathrm{~s}$ for a one-cycle measurement, which includes the waiting time for the magnetic hysteresis stabilization. The detection limits, which were computed as three times the standard deviation of the background noise, for the Au and As measurements were $15 \mathrm{ppb}$ and $0.6 \mathrm{ppm}$, respectively, for an ${ }^{34} \mathrm{~S}$ count of $3 \times 10^{5} \mathrm{cps}$ if the background noise is assumed to have a Poisson distribution. The analysis size using the IMS 1270 was $3 \mu \mathrm{m}$.

The sulfur isotope ratios of pyrite grains from the KDC West deposit were measured using the multi-collection system of the SIMS spectrometer with Faraday cups. The analyzed area on the sample surface is a circle with a diameter of $20 \mu \mathrm{m}$, the same area as the primary beam bombardment; therefore, depth profiling is not available. The primary beam intensity was increased to $1 \mathrm{nA}$ to obtain a high intensity of ${ }^{32} \mathrm{~S}$ secondary ions $\left(2 \times 10^{8} \mathrm{cps}\right)$ for high-precision sulfur isotope measurements. The measured data were normalized using a standard pyrite sample $\left(\delta^{34} \mathrm{~S}=+5.1 \%\right.$ o $)$ and are reported relative to Canyon Diablo Troilite (CDT). The accuracy is less than $\pm 0.2 \%$ o $(2 \sigma)$. The analysis size using the IMS 1270 for sulfur isotope ratios was $20 \mu \mathrm{m}$.

A NanoSIMS 50 at the Atmosphere and Ocean Research Institute (AORI) of the University of Tokyo was used for the analysis of several samples, as indicated in Table 2. After pre-sputtering with a $500 \mathrm{pA} \mathrm{Cs}^{+}$rastered beam over a $30 \mu \mathrm{m} \times 30 \mu \mathrm{m}$ area to remove the carbon coat from the sample surface and stabilize the secondary ion intensity by $\mathrm{Cs}^{+}$implantation, a focused 30 to $50 \mathrm{pA} \mathrm{Cs}^{+}$ primary ion beam was scanned over the inner $20 \mu \mathrm{m} \times 20 \mu \mathrm{m}$ area for analysis. An electron flood gun was used for the purpose of charge compensation. Negative secondary ions were extracted by an accelerating voltage of $8 \mathrm{kV}$ and introduced into the mass spectrometer. The matrix ${ }^{34} \mathrm{~S}^{-}$and the secondary ${ }^{75} \mathrm{As}^{-}$and ${ }^{197} \mathrm{Au}^{-}$ions were measured simultaneously using multi-collectors with EMs. The beam intensity of ${ }^{34} \mathrm{~S}^{-}$was approximately $3.3 \times 10^{5}$ to $3.8 \times 10^{5} \mathrm{cps}$. The dead time ( 44 ns) of the counting system was corrected. The entrance slit was set to a width of approximately $40 \mu \mathrm{m}$, and the exit slits for each EM were set to a width of $75 \mu \mathrm{m}$. A mass-resolving power of 8000 was attained with adequate flat-topped peaks. To reduce background noise and contamination from the area surrounding the analyzed part, beam blanking was adopted. Only the inner approximately $10 \mu \mathrm{m} \times 10 \mu \mathrm{m}$ area of the scanned area was measured ( $32 \times 32$ pixels out of $64 \times 64$ pixels), meaning that only $25 \%$ of the total secondary ions produced were counted. It took about $1000 \mathrm{~s}$ to carry out one analysis run of 50 cycles. The detection limits, computed as three times the standard deviation of the background noise, for the $\mathrm{Au}$ and $\mathrm{As}$ measurements were $7 \mathrm{ppb}$ and $0.3 \mathrm{ppm}$, respectively, for a ${ }^{34} \mathrm{~S}$ count of $3.3 \times$ $10^{5} \mathrm{cps}$ if the background noise is assumed to have a Poisson distribution. The analysis size using the NanoSIMS 50 was $10 \mu \mathrm{m}$. 
The pyrite grains in ore samples from the Witwatersrand $\mathrm{Au}$ fields were analyzed by electron probe microanalysis (EPMA) for $\mathrm{Fe}, \mathrm{Cu}, \mathrm{Co}, \mathrm{Ni}, \mathrm{As}$, and $\mathrm{S}$ using a JEOL JXA-8900 probe at Shizuoka University operated at $20 \mathrm{kV}$ and $12 \mathrm{nA}$, with natural pyrite $\left(\mathrm{FeS}_{2}\right)$ and Arsenopyrite (FeAsS) and pure metal samples $(\mathrm{Co}, \mathrm{Cu}, \mathrm{Ni})$ as standards. The detection limit was $0.01 \mathrm{wt} \%$ for all the measured elements. The analysis size was $10 \mu \mathrm{m}$.

\subsection{Standardization}

Quantitative SIMS analysis requires the use of reference standards for each element and the analyzed host mineral because of matrix effects on secondary ion intensities. Standard samples for $\mathrm{Au}$ measurements in pyrite and pyrrhotite and for As measurements in pyrite were prepared. Calibration of the Au concentration in a mineral was conducted using external standard samples of pyrite and pyrrhotite that were implanted with ${ }^{197} \mathrm{Au}$ ions at a dosage of $1 \times 10^{15} \mathrm{atoms} / \mathrm{cm}^{2}$ with an implantation energy of $1.6 \mathrm{MeV}$ using the $1.7 \mathrm{MV}$ Tandetron accelerator located at the University of Western Ontario, Canada [20]. Calibration of the As concentration in pyrite was also performed using external standard samples that were implanted with As ions at a dosage of $3 \times 10^{15}$ atoms $/ \mathrm{cm}^{2}$, with an implantation energy of $0.4 \mathrm{MeV}$. After analyzing a standard for depth profiling, the depth of the sputtered borehole was measured using a surface profiler to determine the relative sensitivity factor (RSF), which was used to calculate the concentration in the unknown sample [20]. The calibration of the As concentration in pyrrhotite was conducted using EPMA-determined pyrrhotite samples.

\section{Results}

The results of the Au and As measurements are given in Table 2. Because the detection limits for $\mathrm{Au}$ and As measurements were $15 \mathrm{ppb}$ and $0.6 \mathrm{ppm}$, respectively, at the GSJ SIMS, the last figures of the $\mathrm{Au}$ and As concentrations have some errors at low-level intensities. The detection limits of $8 \mathrm{ppb}$ and $0.3 \mathrm{ppm}$ for Au and As measurements, respectively, at the AORI SIMS might be low enough to guarantee the whole figures in Table 2.

The $\mathrm{Au}$ and As concentrations in the pyrite from the Kasuga deposit vary from 0.04 to $24 \mathrm{ppm}$ and from 1 to $400 \mathrm{ppm}$, respectively (Table 2). The Au and As concentrations in the pyrite from the Iwato deposit vary from 0.16 to $2.8 \mathrm{ppm}$ and from 14 to $43 \mathrm{ppm}$, respectively (Table 2). The Au and As concentrations in pyrite from the Akeshi deposit vary from 0.04 to $34 \mathrm{ppm}$ and from 56 to $1100 \mathrm{ppm}$, respectively (Table 2). The Iwato pyrite grains contain less As than those from the other deposits.

The $\mathrm{Au}$ and As concentrations in the pyrite and pyrrhotite from the Kalahari Goldridge deposit are given in Table 2. In addition to the above results, substantial Au analytical data without As content was obtained at the beginning of this study (Table A1). The Au concentrations in pyrrhotite and pyrite vary from 0.01 to $5.62 \mathrm{ppm}$ and from 0.01 to $0.32 \mathrm{ppm}$, respectively (Table 2, Table A1), whereas the As concentrations in pyrrhotite and pyrite are both low, with a narrow range from 6 to $22 \mathrm{ppm}$ (Table 2). Although the Au-As relationship cannot be ascertained from the Au data alone (Table A1), Au depth profiles were acquired during every Au measurement. The Au concentration of pyrite is very low (less than $0.3 \mathrm{ppm})$.

The analytical results of the pyrite from the South Deep and KDC West deposits in the Witwatersrand Basin are given in Table 2. The Au and As concentrations in the pyrite from the South Deep deposit vary from 0.02 to $1.1 \mathrm{ppm}$ and from 8 to $4000 \mathrm{ppm}$, respectively (Table 2). The Au and As concentrations in the pyrite from the KDC West deposit vary from 0.04 to $0.6 \mathrm{ppm}$ and from 22 to 1500 ppm, respectively (Table 2).

The EPMA analysis results for $\mathrm{Fe}, \mathrm{Cu}, \mathrm{Co}, \mathrm{Ni}, \mathrm{As}$, and $\mathrm{S}$ in pyrite from the South Deep and KDC West deposits are given in Tables A2 and A3, respectively. The analysis positions were allocated near the SIMS analysis points. Most pyrites contain $\mathrm{Co}$ and $\mathrm{Ni}$ in addition to As, but the $\mathrm{Cu}$ concentration is generally negligible (Tables A2 and A3). 
Two sulfur isotope ratios of the pyrite from the KDC West deposit were obtained. The analysis positions were near D3 (core $250 \mu \mathrm{m} \times 350 \mu \mathrm{m}$ subangular) and near D2 (rim $300 \mu \mathrm{m} \times 300 \mu \mathrm{m}$ rounded). The $\delta^{34} \mathrm{~S}$ values in these positions are $+3.0 \%$ ond $+5.8 \%$, respectively.

\section{Discussion}

\subsection{Epithermal Au Deposits}

Figure 4 shows the Au and As concentrations in pyrite from the high-sulfidation Nansatsu-type $\mathrm{Au}$ deposits. Three samples from the Nansatsu-type Au deposits have relatively high Au concentrations of around $30 \mathrm{ppm}$ (Figure 4, Table 2), which are more than the solubility of Au in synthesized pure pyrite (up to $3 \mathrm{ppm}$; [47]). Concerning natural arsenic pyrite, relatively large $\mathrm{Au}^{+}$ions are able to enter the crystal structure when the structure is distorted by As incorporation into the structure $[3,48]$. Among the three high Au samples, two small grains of less than $20 \mu \mathrm{m}$ from the Kasuga deposit have high Au concentrations, and the appearance of the pyrite from the Akeshi deposit is irregular. On the other hand, the low-Au pyrite grains, which contain less Au than the solubility of Au in synthesized pure pyrite [47] regardless of the As content, are all bigger than $50 \mu \mathrm{m}$, with a crystalline appearance. The fluid in the stage (probably late stage) might contain little Au but a moderate amount of As, and the fluid might be slightly saturated with pyrite.

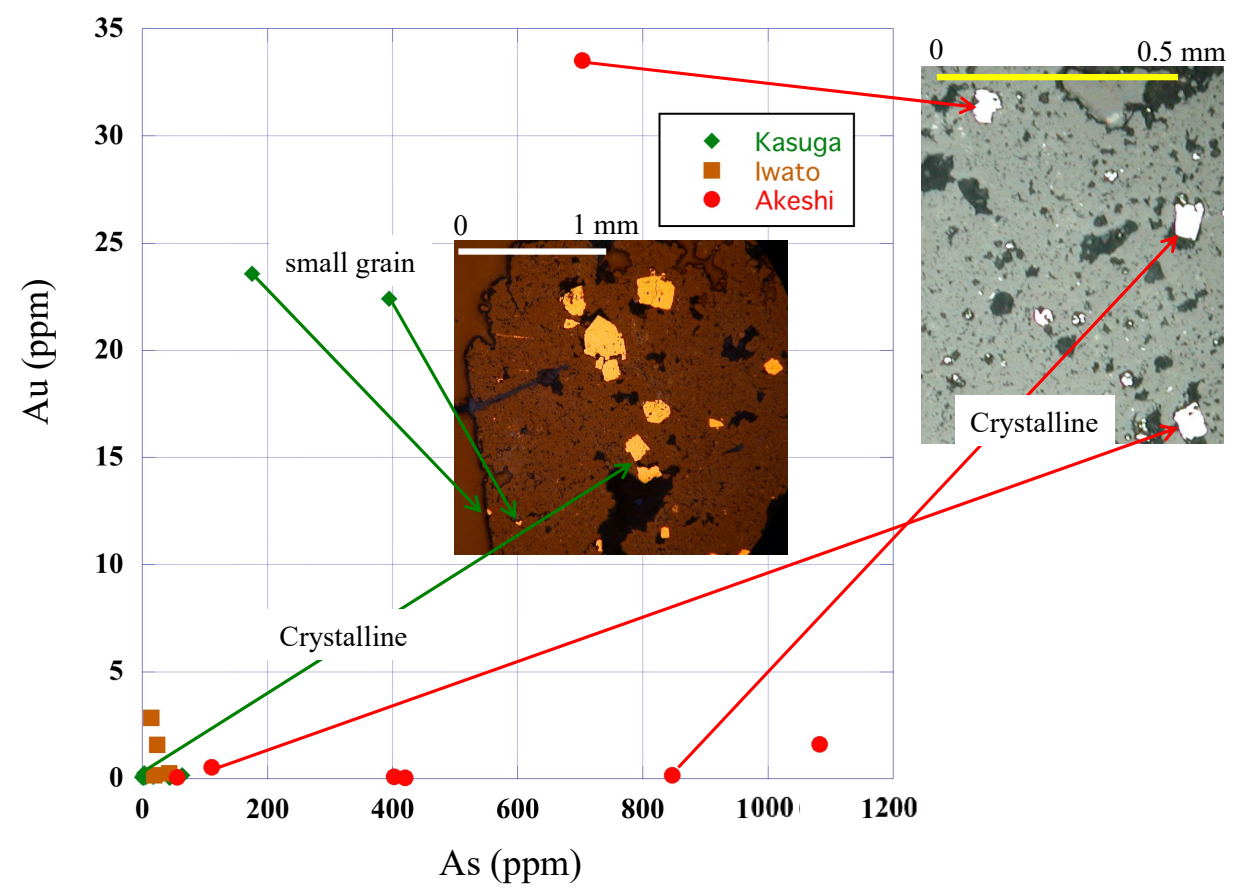

Figure 4. Au and As concentrations (ppm) in pyrite from the high-sulfidation Nansatsu-type (Kasuga, Iwato, and Akeshi) gold deposits. Reflected-light photos showing the shapes of pyrite grains are added to the graph. See Section 5.1 for details.

Regarding the As content, the pyrite grains from the Iwato deposit contain very little As. The other two deposits, the Kasuga and Akeshi deposits, contain relatively high concentrations of As in their pyrite grains. In accordance with the As content in pyrite, the As-containing minerals enargite and luzonite (both of the chemical compositions are $\mathrm{Cu}_{3} \mathrm{AsS}_{4}$ ) occur in the Kasuga and Akeshi deposits, respectively; however, no such minerals were found in the Iwato deposit (Table 1).

At the Hishikari deposit (a typical low-sulfidation Au deposit), the specific value of the Au-As ratio in pyrite proves to be characteristic of the specific Au-bearing vein and its specific depth [20]. The Au-As ratio $\left(3.4 \times 10^{-2}\right)$ is high in the Sanjin ore zone, which consists of high-grade veins in or above the Cretaceous accretionary sedimentary rocks. The Au-As ratio $\left(1 \times 10^{-2}\right)$ is moderate in the 
Honko ore zone, which consists of several high-grade veins, and also occurs in or above the basement sedimentary rocks [20]. In contrast, the Au-As ratio $\left(0.4 \times 10^{-2}\right)$ is gentle in the Yamada ore zone, which consists of relatively low-grade veins, and occurs in Pleistocene andesitic pyroclastic rocks that unconformably overlie the basement sedimentary rocks [20]. According to [20], it may be possible to infer the nature of unknown veins by determining their $\mathrm{Au}-\mathrm{As}$ ratios.

\subsection{Kalahari Goldridge Deposit}

The Au and As concentrations in the pyrite and pyrrhotite from the Kalahari Goldridge deposit are both low (Table 2), and no relationship was found between the two elements. However, the Au concentration in the pyrrhotite varies in a wide range from 0.01 to $5.6 \mathrm{ppm}$ (Table A1). Therefore, the occurrence of $\mathrm{Au}$ in pyrrhotite was examined by SIMS depth analysis.

Figure 5 shows the SIMS depth profile of $\mathrm{Au}$ in a Kalahari pyrrhotite sample (Au1*14.adp in Table A1). The sample surface was bombarded by a $\mathrm{Cs}^{+}$beam, which formed a crater on the sample surface, and the $\mathrm{Au}^{-}$ion count was measured along with the matrix ${ }^{34} \mathrm{~S}^{-}$ion count as a reference. The measurement of the depth of the resulting crater allows the conversion of the time scale to a depth scale (horizontal axis in Figure 5) because the primary beam current stability was fairly good (fluctuation of $1 \%-2 \%$ ) during the measurement. The left-hand vertical axis shows the Au intensity in counts per second, and the right-hand vertical axis shows the raw data converted into the Au concentration in parts per million based on the relative sensitivity factor (RSF). Because the Au intensity is normalized by the intensity of the reference ${ }^{34} \mathrm{~S}$, the measured $\mathrm{Au}$ variation is not caused by instrumental instability or fluctuation but represents the actual variation in Au content with the depth. Figure 5 shows that the pyrrhotite contains $\mathrm{Au}$ in concentrations that vary with depth from 1 to $16 \mathrm{ppm}$, with an average concentration of $5.6 \mathrm{ppm}$ (Table A1). The presence of several peaks in the Au concentration with widths of $50 \mathrm{~nm}$, as shown in Figure 5, suggest that Au occurs as NPs rather than as a solid solution in the pyrrhotite lattice. The high spatial resolution of $3 \mathrm{~nm}$ along the depth direction in the SIMS analysis is characteristically useful in assessing the presence of Au NPs.

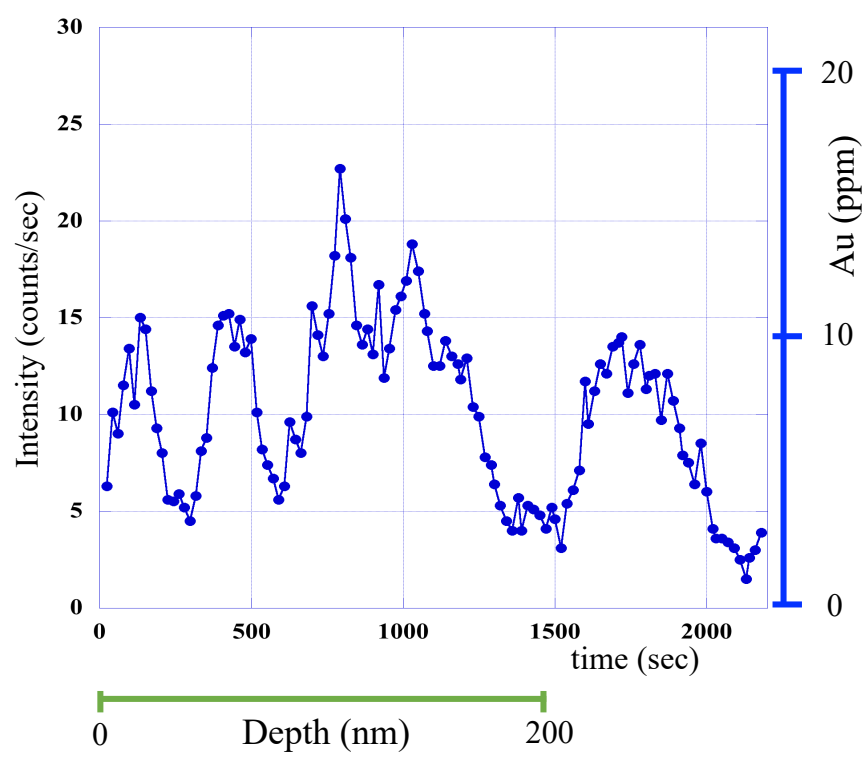

Figure 5. Secondary ion mass spectrometry (SIMS) depth profile of Au in pyrrhotite (Au1*14.adp in Table A1) from the Kalahari Goldridge deposit. The analysis started at the surface of the pyrrhotite grain (left end of the graph) and proceeded toward the interior (right end of the graph), resulting in the formation of a crater. The left vertical axis shows the raw data in counts per second. The right vertical axis shows the Au concentration (ppm) in pyrite calculated from the raw data using the $\mathrm{RSF}_{\mathrm{Au} \text {-pyrrhotite }}$ value. Note that the crater is very shallow and several peaks of Au with of approximately $50 \mathrm{~nm}$ in width (Au nanoparticles (NPs)) were observed. RSF: relative sensitivity factor. 
$\mathrm{Au}$ NPs in pyrrhotite are not uncommon in the Kalahari Goldridge deposit, so similar depth profiles in pyrrhotite are shown in Figure A1 (34S_Au4*111.adp in Table A1) and Figure A2 (34S_Au4*105.adp in Table A1). In contrast, pyrite has little Au, and no Au NPs were detected in the Kalahari Goldridge deposit samples. The depth profile in Figure A3 (Au1*47.adp in Table A1) shows only low signals. The existence of $\mathrm{Au}$ NPs is important when the preconcentration of Au by sulfide flotation is considered.

\subsection{Witwatersrand Au Field}

Pyrite grains from the South Deep deposit show a positive correlation between Au and As (Figure 6). The coefficient of determination $R^{2}$ is 0.71 . The angular grains have more As than the subangular or rounded grains (Figure 6, Table 2). Figure 7 shows an area of lower concentrations of the $\mathrm{Au}-\mathrm{As}$ relationship in the subangular and rounded pyrite grains from the South Deep deposit. The rims of the pyrite grains contain more As than their cores do (Figure 7, Table 2). Both the rim and core of the rounded pyrite grains contain little Au or As.

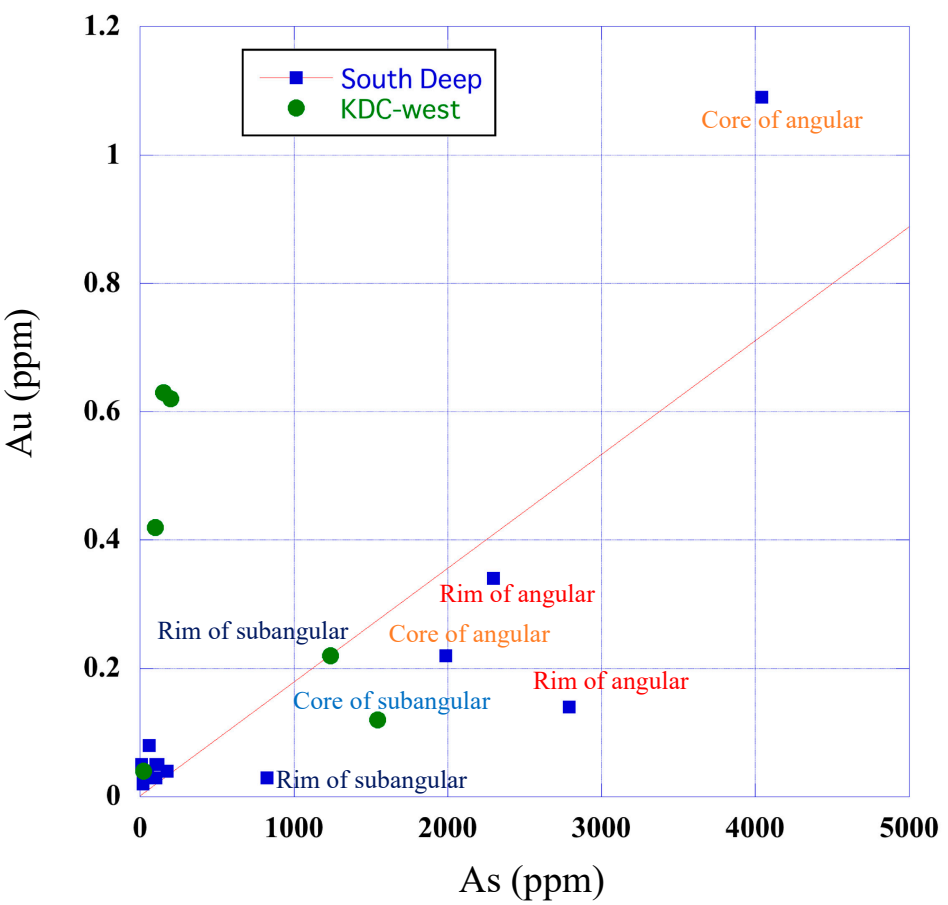

Figure 6. Relationship between Au and As concentrations (ppm) in pyrite from the South Deep and KDC West deposits. A rough positive correlation $\left(R^{2}=0.71\right)$ between the Au and As concentrations was obtained for the South Deep pyrite, whereas the relationship for the KDC West deposit showed different behavior from that of the South Deep deposit. The analysis position (rim or core) and the shape of the pyrite are given near the symbol.

The roundness of the grains is an indicator of the degree of abrasion during transportation in the sedimentary basin. Conversely, angularity may be caused by precipitation from various types of hydrothermal fluids. In the latter case, the rim of a grain may be composed of precipitation from a fluid while the core is of sedimentary origin. These suggest a hydrothermal influence on pyrite formation in the South Deep deposit. The rounded pyrite is sedimentary in origin, and the angular pyrite is thought to have precipitated from hydrothermal fluids. The subangular pyrite may be partly influenced by a late-stage hydrothermal fluid. The As concentration in rounded pyrite from the KDC West deposit is also low, which is similar to the case of the South Deep rounded pyrite; however, in contrast to the South Deep rounded pyrite, its Au content varies (Figure 6).

The $\delta^{34} \mathrm{~S}$ values of the D3 sample (subangular pyrite) and the D2 sample (rounded pyrite) from the KDC West deposit are $+3.0 \%$ ond $+5.8 \%$, respectively. In a previous paper, the broader range 
of the $\delta^{34} \mathrm{~S}$ values for rounded pyrite (from $-4.7 \%$ o to $+6.7 \%$ ) confirms its heterogeneous sulfur composition [49]. This heterogeneity supports the presumption that the rounded pyrite has a placer origin $[40,49]$. Additionally, the euhedral pyrite and pyrite overgrowths have a restricted $\delta^{34} \mathrm{~S}$ range (from $-0.5 \%$ o to $+2.5 \%$ ) [49]. The $\delta^{34} \mathrm{~S}$ values of the rounded and subangular pyrite grains at the KDC West deposit are consistent with published data. The $\delta^{34} S$ value of subangular pyrite is slightly higher than the upper limit of the range because the subangular grain might be a mixture of pyrites with placer and hydrothermal origins. Concerning the subangular pyrite from the KDC West deposit, the $\mathrm{Au}$-As relationship is similar to that of the angular pyrite from the South Deep deposit (Figure 6), which might also be influenced by hydrothermal fluids. The shape of the pyrite grains might prove to be an indicator of hydrothermal influence on sedimentary deposits.

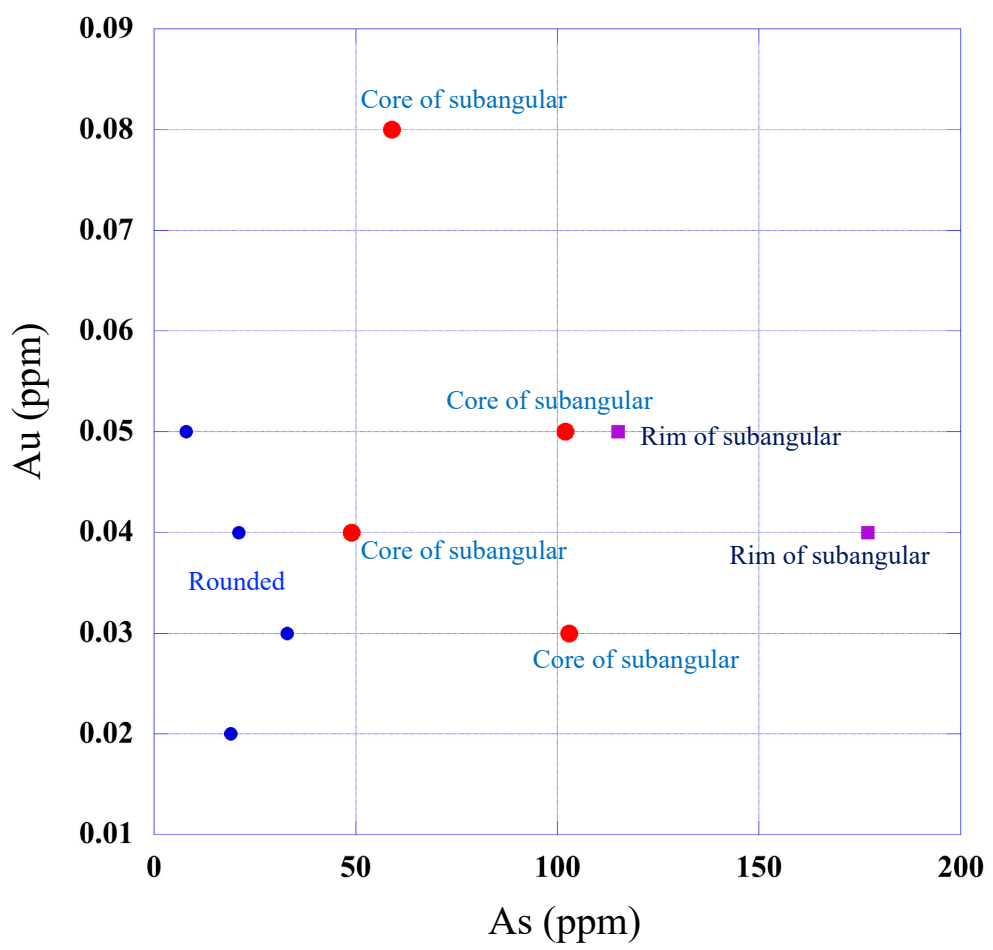

Figure 7. Relationship between Au and As concentrations (ppm) in pyrite from the South Deep deposit (an area of lower Au and As concentrations of Figure 6). The analysis position (rim or core) and the shape of the pyrite are given near the symbol. Violet and red symbols represent data collected at the rim and core of subangular grains, respectively. Rounded grains are shown in blue.

\subsection{Au-As Relationship}

Figure 8 shows all the SIMS data of the Au and As concentrations in pyrite and pyrrhotite (Table 2) in a $\log -\log$ plot of their molar content. The solid line represents the empirical solubility limit of $\mathrm{Au}$ as a function of the As concentration [18]. Almost all the data lie on or below the line. The blue symbols represent high-sulfidation epithermal pyrite from the three Nansatsu-type deposits. The data are scattered over wide ranges of both $\mathrm{Au}$ and As contents. The analysis of one sample from the Kasuga deposit (Au5*260.adp, Table 2) is above the Au solubility limit; however, there are no Au NPs in the pyrite, because the depth profile shows constant Au intensity. Green symbols represent pyrite grains from $\mathrm{Au}$ deposits in the Witwatersrand Au field. The Au and As concentrations are scattered over relatively wide ranges, but a high Au content is not found in any sample. Orange circles represent pyrite (solid) and pyrrhotite (open) from the BIF-hosted Kalahari deposit. They have a narrow range of As concentrations but are scattered over a wide range of Au concentrations. Other than the rough positive correlation between $\mathrm{Au}$ and As concentrations in the South Deep deposit $\left(R^{2}=0.71\right.$; Figure 6), clear $\mathrm{Au}-\mathrm{As}$ correlations are not seen in Figure 8. The reason why there are few $\mathrm{Au}-\mathrm{As}$ correlations 
might partly be because of later-stage hydrothermal $\mathrm{Au}$ and As precipitations onto the existing pyrite surfaces, and additionally, because the majority of Au concentrations in Figure 8 are below 3 ppm (experimental Au solubility limit for pure pyrite) [47].

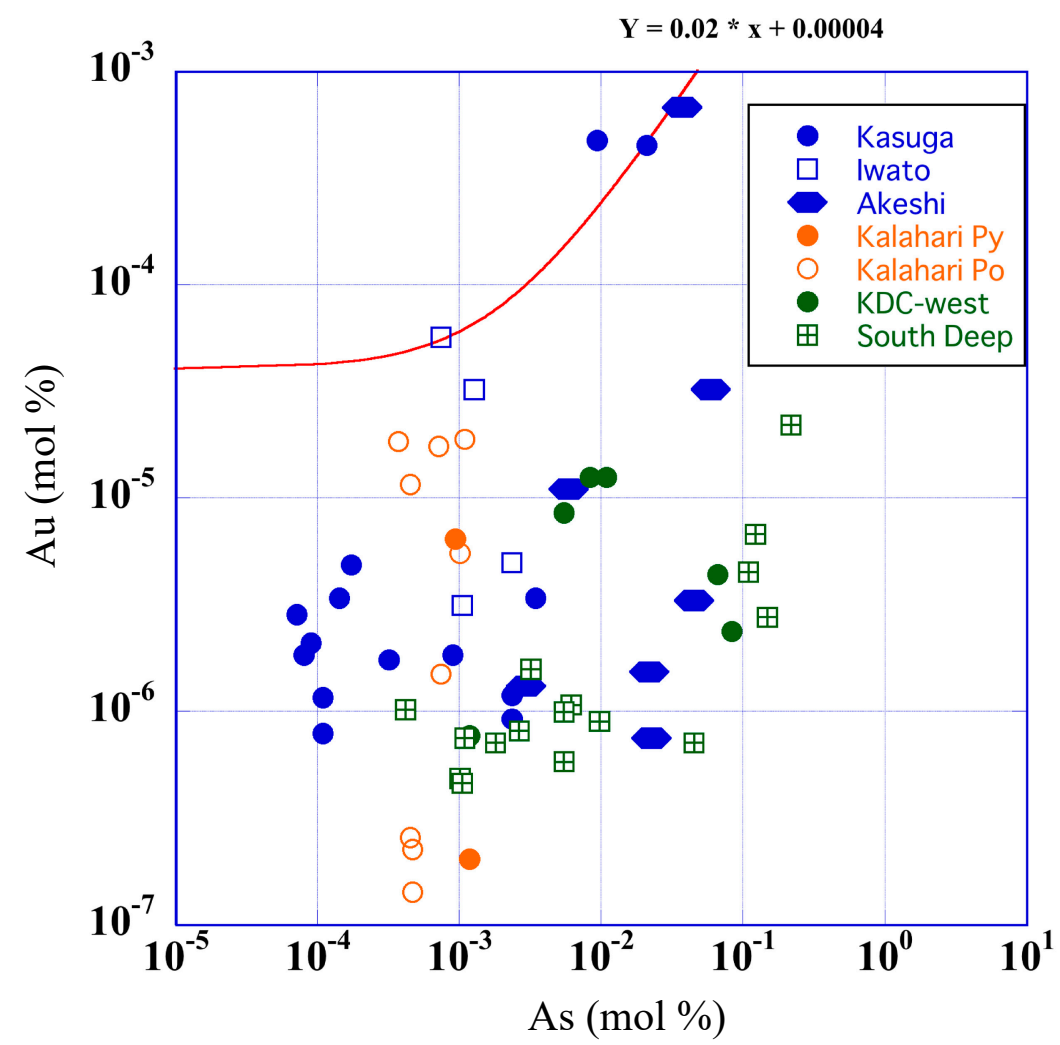

Figure 8. Log-log plot of the relationship between the Au and As concentrations (mol\%), including all the SIMS data for the pyrite and pyrrhotite. Every deposit is allocated a symbol in the legend. The solid line represents the empirical solubility limit of Au in pyrite as a function of As concentration [18]. Note that almost all the data lie on or below the line. See Section 5.4 for details. The labels 'Kalahari Py' and 'Kalahari Po' represent pyrite and pyrrhotite grains, respectively, from the Kalahari deposit.

Figure 5 shows that the Au in pyrrhotite grains exists as Au NPs. Although the As concentration of the grains was not analyzed, the narrow range of As concentrations for the Kalahari deposit would restrict the value. The Au content of $5.62 \mathrm{ppm}$ (Table A1) corresponds to $1.23 \times 10^{-4} \mathrm{~mol} \%$, which is above the solubility limit of Au for pyrite in Figure 8 when the As concentration is in the range for the Kalahari pyrrhotite. In contrast, the As concentrations of pyrrhotite for A1 (34S_Au4*111.adp in Table A1) and A2 (34S_Au4*105.adp in Table A1) correspond to $2.8 \times 10^{-5}$ and $1.9 \times 10^{-5} \mathrm{~mol} \%$, respectively, which are below the solubility limit of Au for pyrite in Figure 8 when the As concentration is in the range for the Kalahari pyrrhotite. This suggests either the Au solubility limit of pyrrhotite is lower than that for pyrite or Au could exist in the form of Au NPs despite the sulfide being below the Au solubility limit [20,50]. In any case, the information on the existence of Au NPs is of great significance in the processing of Au-bearing ore by sulfide flotation because sufficient extraction of $\mathrm{Au}$ depends on the mode of Au occurrence in the sulfides.

Figure 9 compares the $\mathrm{Au}$-As relationship with that from the high-grade low-sulfidation epithermal Hishikari data [20]. The Au solubility limit is also shown. The Hishikari pyrite grains contain more Au and As than the pyrite and pyrrhotite grains analyzed in this study. The As range of the Hishikari host rocks is scattered similarly to that of the Hishikari ore, and the Au range of the Hishikari host rocks is similar to that of the Witwatersrand Basin. 


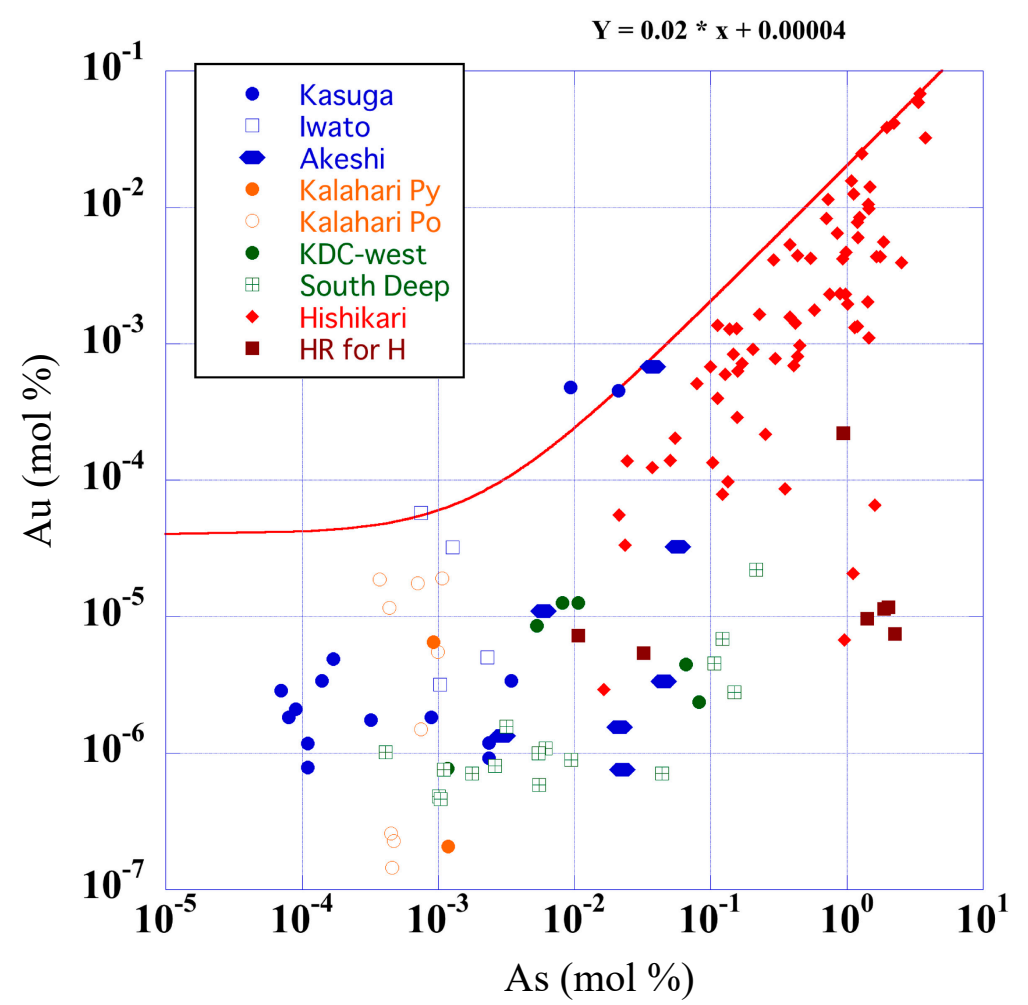

Figure 9. Log-log plot of the relationship between the Au and As concentrations (mol\%), including all the SIMS data for the pyrite and pyrrhotite. The Au-As relationship in pyrite from the Hishikari deposit [20] is included for reference. The solid line represents the empirical solubility limit of Au in pyrite as a function of As concentration [18]. The labels 'Hishikari' and 'HR for $\mathrm{H}^{\prime}$ represent pyrite grains in ore veins and host rocks, respectively, from the Hishikari deposit.

\section{Conclusions}

Pyrite is the principal sulfide of most Au deposits and is ubiquitous in such deposits. The $\mathrm{Au}-\mathrm{As}$ relationships in pyrite and pyrrhotite from epithermal, BIF-hosted, and sedimentary Au deposits were determined by SIMS. The Au and As concentrations in pyrite varied from 0.04 to $30 \mathrm{ppm}$ and from 1 to 1000 ppm, respectively, in the high-sulfidation Nansatsu-type epithermal deposits. Both concentrations are lower than those of the low-sulfidation epithermal Hishikari deposit, where the $\mathrm{Au}$ and As concentrations in pyrite range from 0.1 to $2800 \mathrm{ppm}$ and from 0 to $70,000 \mathrm{ppm}(7 \mathrm{wt} \%)$, respectively [20]. The Au concentrations in pyrrhotite and pyrite reach 6 and $0.3 \mathrm{ppm}$, respectively, in the Kalahari Goldridge BIF-hosted Au deposit, and the Au contained in the pyrrhotite might sometimes exist in the form of NPs, whereas the As concentrations in pyrrhotite and pyrite are low and lie in a narrow range from 6 to $22 \mathrm{ppm}$. The existence of Au NPs is important when preconcentration of Au by sulfide flotation is considered, while the existence of lattice Au cannot be confirmed. The Au and As concentrations in pyrite from the Witwatersrand Au field range from 0.02 to $1.1 \mathrm{ppm}$ and from 8 to $4000 \mathrm{ppm}$, respectively. The Au and As concentrations of almost all the pyrites lie on or below the $\mathrm{Au}$ solubility limit [18], indicating that $\mathrm{Au}^{+}$is the dominant form of $\mathrm{Au}$ in the studied pyrites. The shape of the pyrite from a sedimentary deposit might prove to be an indicator of the hydrothermal influence on the deposit, which is supposed to relate with the genesis of the deposit. This study will further demonstrate that the analysis of $\mathrm{Au}$ and As concentrations in pyrite from other ore deposits could elucidate the genesis of the deposits.

Author Contributions: Conceptualization: Y.M., N.Q.H., and H.U. Methodology: Y.M. Formal analysis: Y.M. Investigation: Y.M., Y.S., and N.T. (SIMS); and K.M. and R.K. (EPMA). Resources: Y.M., N.Q.H., K.M., R.K., and H.U. Writing — original draft preparation: Y.M. Writing—review and editing: All authors. Project administration: Y.M., N.Q.H., and H.U. Funding acquisition: Y.M. 
Funding: This research was funded by the Japan Society for the Promotion of Science (JSPS) Kakenhi grant numbers 15K05340 and 18K03758; the Japan Mining Promotive Foundation (Nihon Kogyo Shinkokai); the Geological Survey of Japan, AIST; and the Atmosphere and Ocean Research Institute, University of Tokyo.

Acknowledgments: The authors are grateful to geologists at the Kasuga, Iwato, Akeshi, Kalahari Goldridge, South Deep and KDC West mines for providing ore samples. The author (Y.M.) is indebted to Genji Saito and Isoji Miyagi of the Geological Survey of Japan for their help with SIMS analyses.

Conflicts of Interest: The authors declare no conflict of interest.

\section{Appendix A}
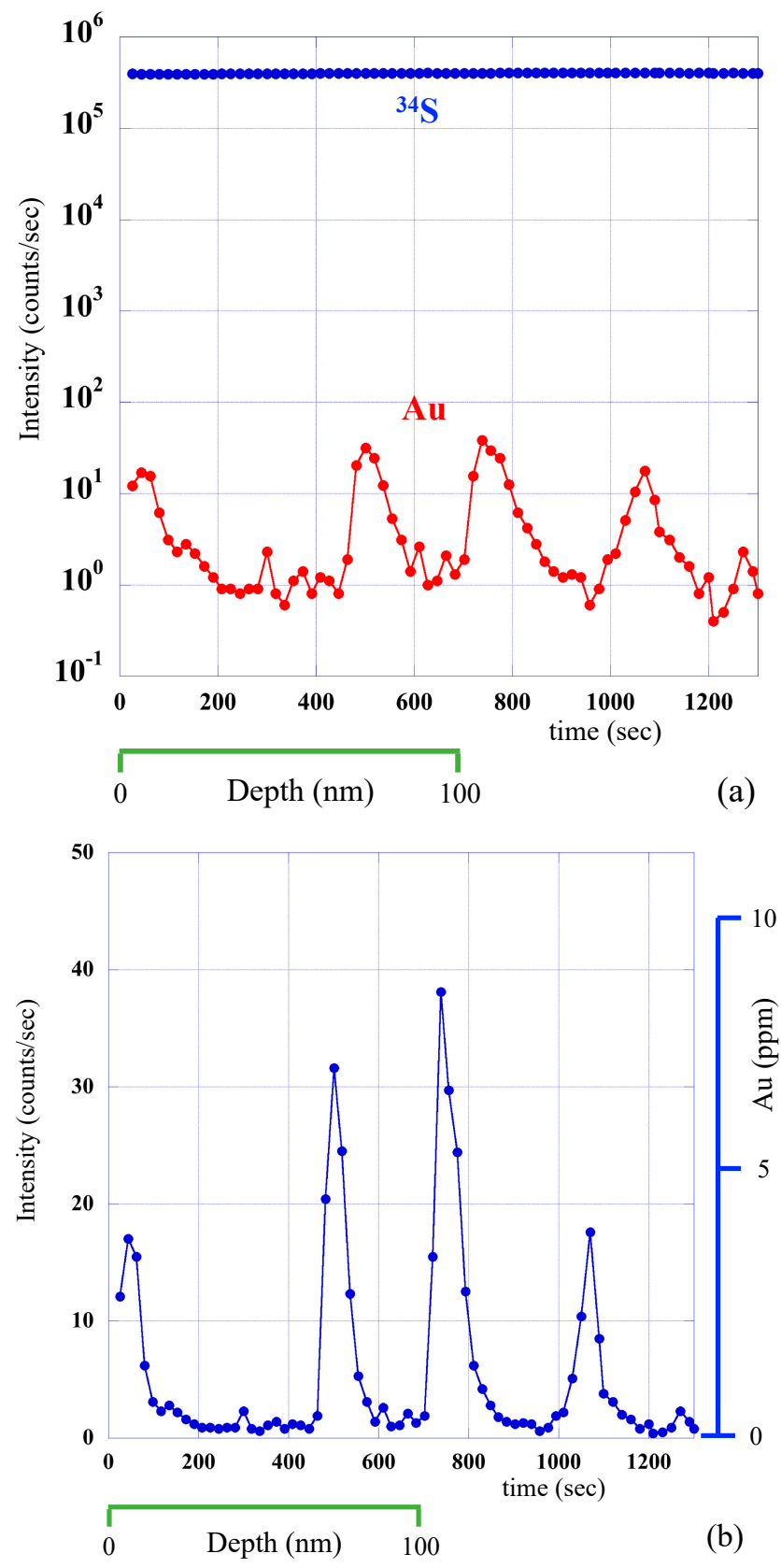

Figure A1. Depth profiles in pyrrhotite (34S_Au4*111.adp in Table A1) from the Kalahari Goldridge deposit. (a) Au and ${ }^{34} \mathrm{~S}$ intensities (cps) on a logarithmic scale plotted against time. The corresponding depth is shown along the time scale. (b) Au intensity on a linear scale. The corresponding Au concentration is shown along the intensity scale. Several peaks corresponding to Au NPs (nanoparticles) are present in the profile. 


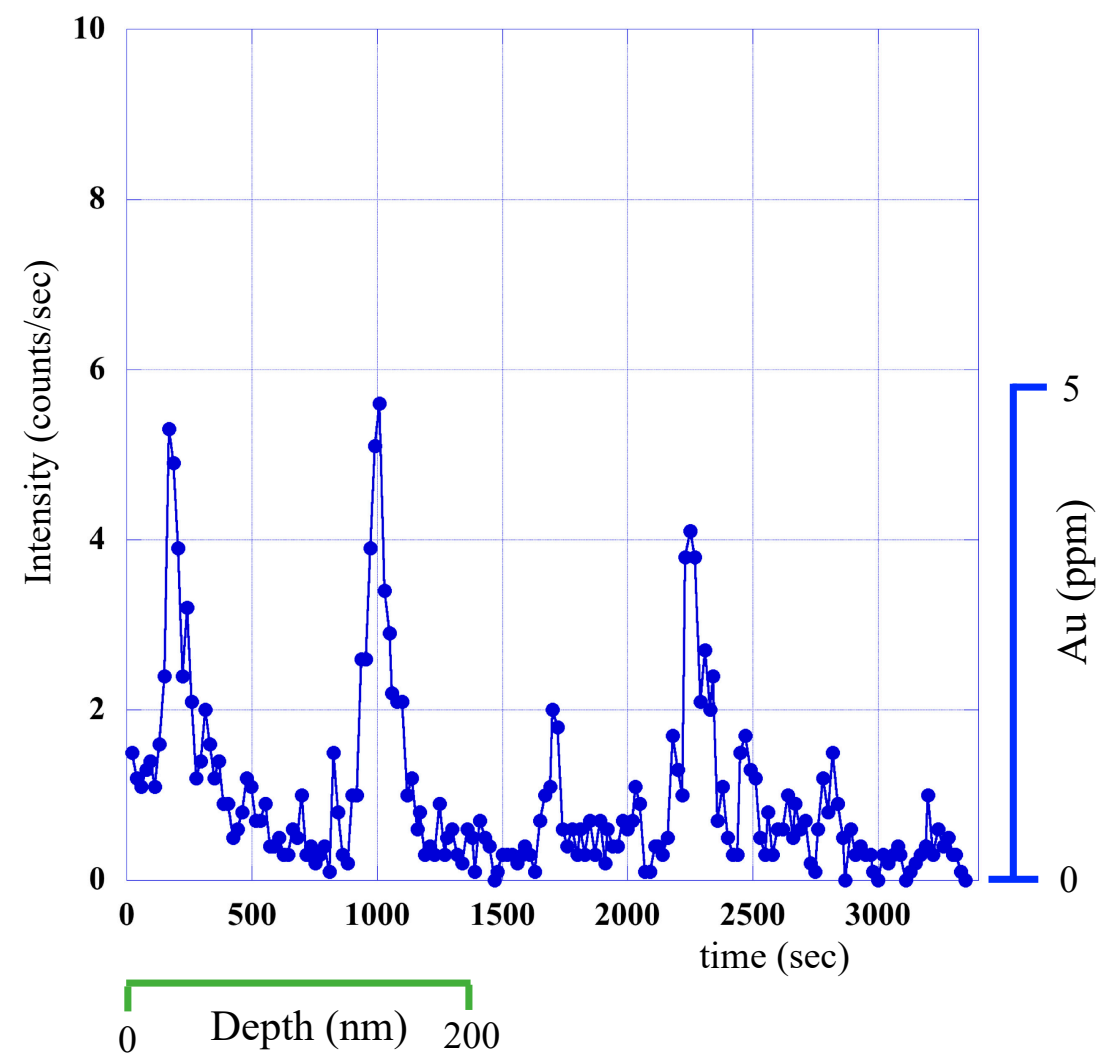

Figure A2. Depth profile of Au concentration in pyrrhotite (34S_Au4*105.adp in Table A1) from the Kalahari Goldridge deposit. Several peaks corresponding to Au NPs are present in the profile.

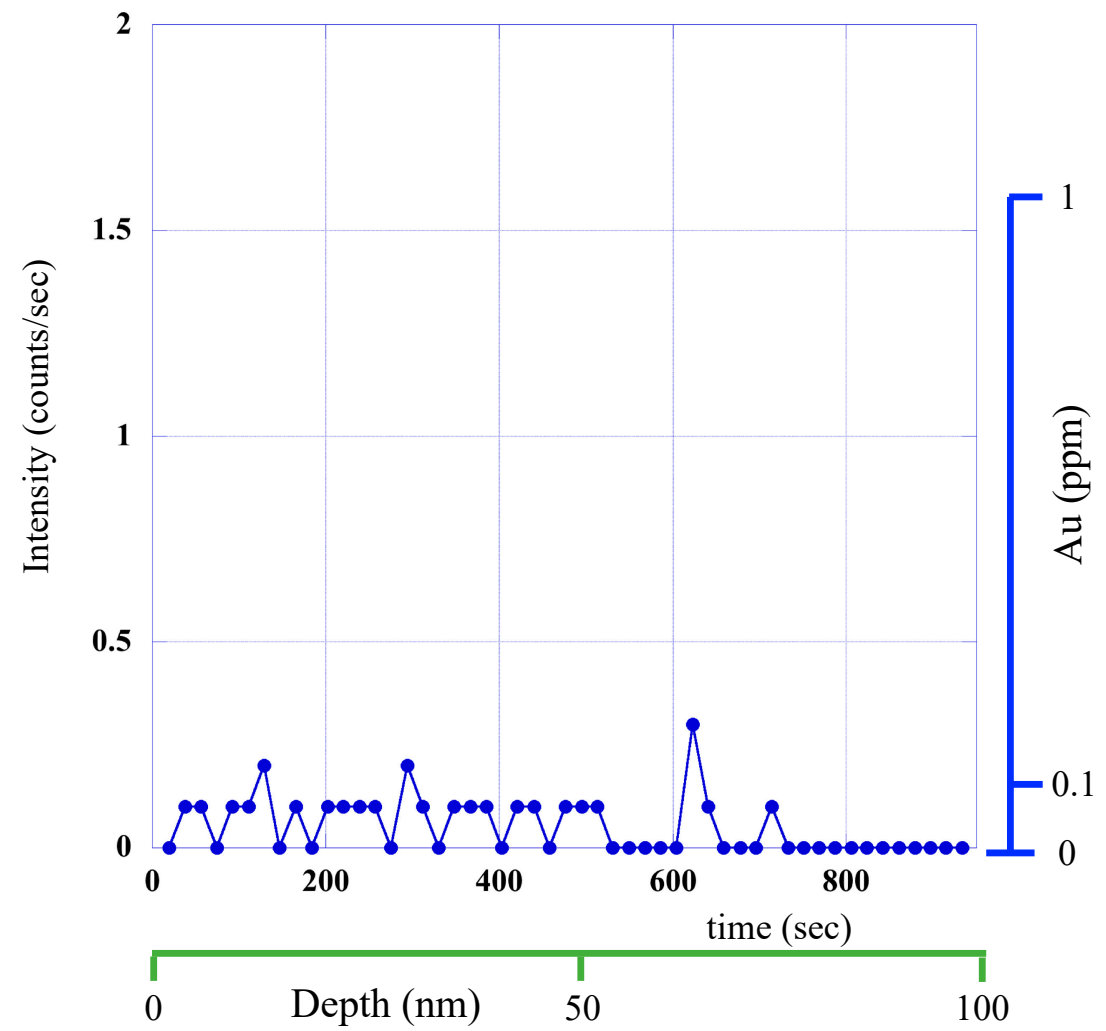

Figure A3. Depth profile of Au concentration vs. depth in pyrite (Au1*47.adp in Table A1) from the Kalahari Goldridge deposit. No peaks corresponding to Au NPs are present in the profile. The Au concentration is very low and includes EM (electron multiplier) background noise. 


\section{Appendix B}

Table A1. Results of the SIMS Au analysis of pyrite and pyrrhotite grains from the Kalahari deposit.

\begin{tabular}{|c|c|c|c|c|c|c|}
\hline $\begin{array}{c}\text { Sample } \\
\text { Name }\end{array}$ & Deposit & Loc & $\begin{array}{c}\text { Analysis } \\
\text { Spot }\end{array}$ & Analysis No. & Mineral & $\begin{array}{c}\mathrm{Au} \\
(\mathrm{ppm})\end{array}$ \\
\hline GDP636/72/B & D zone & & \#9 & Au1*13.adp & Pyrrhotite & 0.05 \\
\hline GDP636/72/B & D zone & & $\# 10$ & Au1*14.adp & Pyrrhotite & 5.62 \\
\hline GDP636/72/B & D zone & & $\# 12$ & Au1*16.adp & Pyrrhotite & 0.06 \\
\hline $118 / 21 / 15 \mathrm{~A}$ & D zone & north pit BIF & \#6 py-1 & Au1*23.adp & Pyrite-crystalline & 0.26 \\
\hline $118 / 21 / 15 \mathrm{~A}$ & D zone & north pit BIF & \#7 po-3 & Au1*24.adp & Pyrrhotite & 0.05 \\
\hline 118/21/15A & D zone & north pit BIF & \#11 ро-5 & Au1*28.adp & Pyrrhotite & 0.69 \\
\hline 118/21/15A & D zone & north pit BIF & \#14 po-8 & Au1*31.adp & Pyrrhotite & 0.55 \\
\hline 118/21/15A & D zone & north pit BIF & \#16 po-10 & Au1*34.adp & Pyrrhotite & 1.75 \\
\hline DD18/18/1B & D zone & south pit BIF & \#2 po-1 & Au1*45.adp & Pyrrhotite & 0.02 \\
\hline DD18/18/1B & D zone & south pit BIF & \#3 py-1 & Au1*47.adp & Pyrite & 0.03 \\
\hline DD18/18/1B & D zone & south pit BIF & \#5 po-2 & Au1*48.adp & Pyrrhotite & 0.04 \\
\hline DD18/18/1B & D zone & south pit BIF & \#6 po-3 & Au1*49.adp & Pyrrhotite & 0.04 \\
\hline DD18/18/1B & D zone & south pit BIF & \#8 po-4 & Au1*51.adp & Pyrrhotite & 0.09 \\
\hline $118 / 21 / 11 \mathrm{~A}$ & D zone & north pit BIF & \#3 & Au1*52.adp & Pyrite & 0.04 \\
\hline $118 / 21 / 11 \mathrm{~A}$ & D zone & north pit BIF & $\# 8$ & Au1*56.adp & Pyrrhotite & 0.14 \\
\hline $118 / 21 / 11 \mathrm{~A}$ & D zone & north pit BIF & \#9 & Au1*57.adp & Pyrrhotite & 0.28 \\
\hline GDP636/72/B & D zone & & $\# 3$ py-1 & Au1*58.adp & Pyrite & 0.14 \\
\hline GDP636/72/B & D zone & & \#8 po-4 & Au1*64.adp & Pyrrhotite & 0.11 \\
\hline GDP636/72/B & D zone & & \#9 po-5 & Au1*65.adp & Pyrrhotite & 0.09 \\
\hline 118/21/8B & D zone & north pit BIF & \#2 py-1 & Au1*68.adp & Pyrite & 0.03 \\
\hline $118 / 21 / 8 \mathrm{~B}$ & D zone & north pit BIF & \#5 po-2 & Au1*70.adp & Pyrrhotite & 0.07 \\
\hline $118 / 21 / 8 \mathrm{~B}$ & D zone & north pit BIF & \#7 py-2 & Au1*73.adp & Pyrite & 0.01 \\
\hline 118/21/8B & D zone & north pit BIF & \#9 po-5 & Au1*75.adp & Pyrrhotite & 0.07 \\
\hline $118 / 21 / 15 \mathrm{~A}$ & D zone & north pit BIF & \#20 ро-20 & 34S_Au4*102.adp & Pyrrhotite & 0.08 \\
\hline $118 / 21 / 15 \mathrm{~A}$ & D zone & north pit BIF & \#21 ро-21 & 34S_Au4*103.adp & Pyrrhotite & 0.10 \\
\hline $118 / 21 / 15 \mathrm{~A}$ & D zone & north pit BIF & \#22 ро-22 & 34S_Au4*104.adp & Pyrrhotite & 1.29 \\
\hline $118 / 21 / 15 \mathrm{~A}$ & D zone & north pit BIF & \#22 ро-22 & 34S_Au4*111.adp & Pyrrhotite & 1.28 \\
\hline $118 / 21 / 15 \mathrm{~A}$ & D zone & north pit BIF & \#23 ро-23 & 34S_Au4*105.adp & Pyrrhotite & 0.89 \\
\hline $118 / 21 / 15 \mathrm{~A}$ & D zone & north pit BIF & \#23 ро-23 & 34S_Au4*112.adp & Pyrrhotite & 0.66 \\
\hline $118 / 21 / 15 \mathrm{~A}$ & D zone & north pit BIF & \#24 ро-24 & 34S_Au4*106.adp & Pyrrhotite & 0.06 \\
\hline $118 / 21 / 15 \mathrm{~A}$ & D zone & north pit BIF & \#25 ро-25 & 34S_Au4*107.adp & Pyrrhotite & 0.49 \\
\hline $118 / 21 / 15 \mathrm{~A}$ & D zone & north pit BIF & \#26 ро-26 & 34S_Au4*108.adp & Pyrrhotite & 0.58 \\
\hline 118/21/15A & D zone & north pit BIF & \#27 po-27 & 34S_Au4*109.adp & Pyrrhotite & 0.41 \\
\hline
\end{tabular}

Table A2. Results of the EPMA analysis of pyrite from the South Deep deposit.

\begin{tabular}{ccccccccc}
\hline $\begin{array}{c}\text { Analysis } \\
\text { Spot }\end{array}$ & $\begin{array}{c}\text { Analysis } \\
\text { Position }\end{array}$ & Fe (wt\%) & $\begin{array}{c}\mathbf{C u} \\
\mathbf{( w t \% )}\end{array}$ & $\begin{array}{c}\text { Co } \\
\mathbf{( w t \% )}\end{array}$ & $\mathbf{N i} \mathbf{( w t \% )}$ & $\begin{array}{c}\text { As } \\
(\mathbf{w t} \%)\end{array}$ & $\mathbf{S}(\mathbf{w t} \%)$ & $\begin{array}{c}\text { Total } \\
\mathbf{( w t} \%)\end{array}$ \\
\hline 11 & core S11 & 45.85 & - & 0.36 & 0.08 & 0.04 & 53.60 & 99.93 \\
12 & rim S12 & 46.41 & - & 0.10 & 0.11 & 0.01 & 54.32 & 100.94 \\
14 & core S13 & 46.73 & 0.02 & 0.04 & 0.01 & - & 53.77 & 100.57 \\
15 & rim S14 & 46.15 & - & 0.09 & 0.08 & 0.05 & 54.01 & 100.37 \\
5 & core S15, S27 & 46.05 & 0.04 & 0.05 & - & 0.18 & 53.85 & 100.17 \\
6 & rim S16, S26 & 46.67 & - & 0.05 & 0.02 & 0.32 & 53.82 & 100.88 \\
7 & rim S16, S26 & 46.21 & 0.01 & 0.07 & 0.04 & 0.25 & 54.03 & 100.60 \\
8 & rim S16, S26 & 46.57 & 0.03 & 0.07 & 0.03 & 0.13 & 52.47 & 99.30 \\
9 & core S24 & 46.37 & - & 0.05 & 0.01 & 0.02 & 53.75 & 100.19 \\
10 & rim S25 & 46.33 & - & 0.10 & 0.03 & - & 52.60 & 99.06 \\
3 & Rim S28 & 46.99 & 0.01 & 0.08 & - & - & 51.87 & 98.95 \\
4 & Rim S28 & 46.32 & - & 0.11 & 0.02 & 0.02 & 53.95 & 100.42 \\
1 & core S29 & 45.62 & - & 0.05 & - & - & 54.70 & 100.37 \\
2 & core S29 & 46.54 & - & 0.07 & 0.02 & 0.00 & 52.72 & 99.35 \\
13 & core S30 & 45.99 & - & 0.22 & - & - & 53.74 & 99.95 \\
\hline
\end{tabular}


Table A2. Cont.

\begin{tabular}{ccccccccc}
\hline $\begin{array}{c}\text { Analysis } \\
\text { Spot }\end{array}$ & $\begin{array}{c}\text { Analysis } \\
\text { Position }\end{array}$ & $\begin{array}{c}\mathbf{F e} \\
(\mathbf{m o l} \%)\end{array}$ & $\begin{array}{c}\mathbf{C u} \\
(\mathbf{m o l} \%)\end{array}$ & $\begin{array}{c}\text { Co } \\
(\mathbf{m o l} \%)\end{array}$ & $\begin{array}{c}\mathbf{N i} \\
(\mathbf{m o l} \%)\end{array}$ & $\begin{array}{c}\text { As } \\
(\mathbf{m o l} \%)\end{array}$ & $\begin{array}{c}\text { S } \\
(\mathbf{m o l} \%)\end{array}$ & $\begin{array}{c}\text { Total } \\
(\mathbf{m o l} \%)\end{array}$ \\
\hline 11 & core S11 & 32.83 & - & 0.25 & 0.06 & 0.02 & 66.85 & 100.00 \\
12 & rim S12 & 32.86 & - & 0.07 & 0.07 & 0.01 & 67.00 & 100.00 \\
14 & core S13 & 33.27 & 0.01 & 0.03 & 0.01 & - & 66.69 & 100.00 \\
15 & rim S14 & 32.86 & - & 0.06 & 0.05 & 0.02 & 67.00 & 100.00 \\
5 & core S15, S27 & 32.87 & 0.03 & 0.04 & - & 0.09 & 66.97 & 100.00 \\
6 & rim S16, S26 & 33.16 & - & 0.04 & 0.01 & 0.17 & 66.62 & 100.00 \\
7 & rim S16, S26 & 32.86 & 0.01 & 0.05 & 0.03 & 0.13 & 66.93 & 100.00 \\
8 & rim S16, S26 & 33.70 & 0.02 & 0.05 & 0.02 & 0.07 & 66.14 & 100.00 \\
9 & core S24 & 33.11 & - & 0.03 & 0.00 & 0.01 & 66.85 & 100.00 \\
10 & rim S25 & 33.56 & - & 0.07 & 0.02 & - & 66.36 & 100.00 \\
3 & Rim S28 & 34.18 & 0.00 & 0.05 & - & - & 65.74 & 99.98 \\
4 & Rim S28 & 32.98 & - & 0.07 & 0.01 & 0.01 & 66.92 & 99.99 \\
1 & core S29 & 32.36 & - & 0.04 & - & - & 67.60 & 100.00 \\
2 & core S29 & 33.61 & - & 0.05 & 0.01 & 0.00 & 66.33 & 100.00 \\
13 & core S30 & 32.89 & - & 0.15 & - & - & 66.95 & 99.99 \\
\hline
\end{tabular}

core S11: Core of the grain, where it is close to S11 in Table 2.

Table A3. Results of the EPMA analysis of pyrite from the KDC West deposit.

\begin{tabular}{|c|c|c|c|c|c|c|c|c|}
\hline $\begin{array}{c}\text { Analysis } \\
\text { Spot }\end{array}$ & $\begin{array}{l}\text { Analysis } \\
\text { Position }\end{array}$ & $\mathrm{Fe}(w \mathrm{t} \%)$ & $\underset{(w t \%)}{\mathrm{Cu}}$ & $\begin{array}{c}\text { Co } \\
(w t \%)\end{array}$ & $\mathrm{Ni}(w \mathrm{t} \%)$ & $\begin{array}{c}\text { As } \\
(w t \%)\end{array}$ & $S(w t \%)$ & $\begin{array}{c}\text { Total } \\
(w t \%)\end{array}$ \\
\hline 1 & rim D1 & 46.03 & - & 0.11 & - & 0.06 & 52.32 & 98.51 \\
\hline 9 & core SgD1 & 45.25 & - & 0.06 & 0.03 & 0.11 & 54.17 & 99.62 \\
\hline 5 & rim SgD3 & 45.62 & - & 0.09 & 0.11 & 0.12 & 53.78 & 99.71 \\
\hline 4 & rim D2 & 45.24 & 0.06 & 0.40 & 0.07 & 0.04 & 53.94 & 99.75 \\
\hline 12 & $\operatorname{rim} \mathrm{D} 2$ & 46.25 & - & 0.29 & 0.13 & 0.02 & 53.17 & 99.86 \\
\hline 13 & $\operatorname{rim} \mathrm{D} 2$ & 45.84 & 0.01 & 0.55 & 0.09 & 0.04 & 52.06 & 98.58 \\
\hline 14 & rim D2 & 46.23 & - & 0.44 & 0.09 & 0.02 & 53.46 & 100.24 \\
\hline $\begin{array}{c}\text { Analysis } \\
\text { Spot }\end{array}$ & $\begin{array}{l}\text { Analysis } \\
\text { Position }\end{array}$ & $\underset{(\mathrm{mol} \%)}{\mathrm{Fe}}$ & $\underset{(\mathrm{mol} \%)}{\mathrm{Cu}}$ & $\begin{array}{c}\text { Co } \\
(\mathrm{mol} \%)\end{array}$ & $\begin{array}{c}\mathrm{Ni} \\
(\mathrm{mol} \%)\end{array}$ & $\underset{(\mathrm{mol} \%)}{\mathrm{As}}$ & $\begin{array}{c}\mathrm{S} \\
(\mathrm{mol} \%)\end{array}$ & $\begin{array}{c}\text { Total } \\
(\mathrm{mol} \%)\end{array}$ \\
\hline 1 & $\operatorname{rim} \mathrm{D} 1$ & 33.52 & - & 0.08 & - & 0.03 & 66.37 & 100.00 \\
\hline 9 & core SgD1 & 32.37 & - & 0.04 & 0.02 & 0.06 & 67.51 & 99.99 \\
\hline 5 & $\operatorname{rim} \mathrm{SgD} 3$ & 32.68 & - & 0.06 & 0.07 & 0.06 & 67.12 & 100.00 \\
\hline 4 & rim D2 & 32.38 & 0.04 & 0.27 & 0.05 & 0.02 & 67.24 & 100.00 \\
\hline 12 & $\operatorname{rim} \mathrm{D} 2$ & 33.20 & - & 0.20 & 0.09 & 0.01 & 66.50 & 100.00 \\
\hline 13 & $\operatorname{rim} \mathrm{D} 2$ & 33.42 & 0.01 & 0.38 & 0.06 & 0.02 & 66.11 & 100.00 \\
\hline 14 & $\operatorname{rim} \mathrm{D} 2$ & 33.05 & - & 0.30 & 0.06 & 0.01 & 66.58 & 100.00 \\
\hline
\end{tabular}

rim D1: rim of the grain, where it is close to D1 in Table 2. core SgD1: core of the same grain as D1 grain.

\section{References}

1. Chryssoulis, S.L.; Cabri, L.J. Significance of gold mineralogical balances in mineral processing. Trans. Inst. Min. Metall. 1990, 99, C1-C10.

2. Palenik, C.S.; Utsunomiya, S.; Reich, M.; Kesler, S.E.; Wang, L.; Ewing, R.C. “Invisible” gold revealed: Direct imaging of gold nanoparticles in a Carlin-type deposit. Am. Min. 2004, 89, 1359-1366. [CrossRef]

3. Deditius, A.P.; Utsunomiya, S.; Renock, D.; Ewing, R.C.; Ramana, C.V.; Becker, U.; Kesler, S.E. A proposed new type of arsenian pyrite: Composition, nanostructure and geological significance. Geochim. Cosmochim. Acta 2008, 72, 2919-2933. [CrossRef]

4. Deditius, A.P.; Utsunomiya, S.; Reich, M.; Kesler, S.E.; Ewing, R.C.; Hough, R.; Walshe, J. Trace metal nanoparticles in pyrite. Ore Geol. Rev. 2011, 42, 32-46. [CrossRef]

5. Tauson, V.L.; Lipko, S.V.; Smagunov, N.V.; Kravtsova, R.G. Trace Element Partitioning Dualism under Mineral-Fluid Interaction: Origin and Geochemical Significance. Minerals 2018, 8, 282. [CrossRef] 
6. Pokrovski, G.S.; Kokh, M.A.; Proux, O.; Hazemann, J.L.; Bazarkina, E.F.; Testemale, D.; Escoda, C.; Boiron, M.C.; Blanchard, M.; Aigouy, T.; et al. The nature and partitioning of invisible gold in the pyrite-fluid system. Ore Geol. Rev. 2019, 109, 545-563. [CrossRef]

7. Chryssoulis, S.L.; Cabri, L.J.; Lennard, W. Calibration of the ion microprobe for quantitative trace precious metal analyses of ore minerals. Econ. Geol. 1989, 84, 1684-1689. [CrossRef]

8. Cabri, L.J.; Chryssoulis, S.L.; de Villiers, J.P.R.; Laflamme, J.H.G.; Buseck, P.R. The nature of “invisible" gold in arsenopyrite. Can. Miner. 1989, 27, 353-362.

9. Chryssoulis, S.L.; Weisener, C.G. Secondary Ion Mass Spectrometry Relative Sensitivity Factors for Ru, Rb, $\mathrm{Pb}, \mathrm{Ag}$, Os, Ir, Pt and Au in Sulfide Minerals. In Secondary Ion Mass Spectrometry: SIMS X; Benninghoven, A., Hagenhoff, B., Werner, H.W., Eds.; John Wiley \& Sons: New York, NY, USA, 1997; pp. 983-986.

10. Cabri, L.J.; McMahon, G. SIMS analysis of sulfide minerals for Pt and Au: Methodology and relative sensitivity factors (RSF). Can. Miner. 1995, 33, 349-359.

11. Larocque, A.C.L.; Cabri, L.J. Ion-microprobe quantification of precious metals in sulfide minerals. Rev. Econ. Geol. 1998, 7, 155-167.

12. Chouinard, A.; Paquette, J.; Williams-Jones, A.E. Crystallographic Controls on Trace-Element Incorporation in Auriferous Pyrite from the Pascua Epithermal High-Sulfidation Deposit, Chile Argentina. Can. Miner. 2005, 43, 951-963. [CrossRef]

13. Morishita, Y.; Hammond, N.Q. Sub-microscopic gold from the Kalahari Goldridge deposit, Kraaipan Greenstone belt, South Africa. In The Ninth Biennial SGA Meeting; Andrew, C.J., Ed.; Irish Association for Econmic Geology: Dublin, Ireland, 2007; Volume 2, pp. 1019-1022.

14. Silberman, M.L.; Berger, B.R. Relationship of trace-element patterns to alteration and morphology in epithermal precious-metal deposits. SEG Rev. Econ. Geol. 1985, 2, 203-232.

15. Cook, N.J.; Chryssoulis, S.L. Concentrations of "invisible gold" in the common sulfides. Can. Miner. 1990, 28, 1-16.

16. Arehart, G.B.; Chryssoulis, S.L.; Kesler, S.E. Gold and arsenic in iron sulfides from sediment-hosted disseminated gold deposits; implications for depositional processes. Econ. Geol. 1993, 88, 171-185. [CrossRef]

17. Pals, D.W.; Spry, P.G.; Chryssoulis, S. Invisible Gold and Tellurium in Arsenic-Rich Pyrite from the Emperor Gold Deposit, Fiji: Implications for Gold Distribution and Deposition. Econ. Geol. 2003, 98, 479-493. [CrossRef]

18. Reich, M.; Kesler, S.E.; Utsunomiya, S.; Palenik, C.S.; Chryssoulis, S.L.; Ewing, R.C. Solubility of gold in arsenian pyrite. Geochim. Cosmochim. Acta 2005, 69, 2781-2796. [CrossRef]

19. Morishita, Y.; Shimada, N.; Shimada, K. Invisible gold and arsenic in pyrite from the high-grade Hishikari gold deposit, Japan. Appl. Surf. Sci. 2008, 255, 1451-1454. [CrossRef]

20. Morishita, Y.; Shimada, N.; Shimada, K. Invisible gold in arsenian pyrite from the high-grade Hishikari gold deposit, Japan: Significance of variation and distribution of Au/As ratios in pyrite. Ore Geol. Rev. 2018, 95, 79-93. [CrossRef]

21. Barton, P.B., Jr.; Skinner, B.J. Sulfide mineral stabilities. In Geochemistry of Hydrothermal Ore Deposits, 2nd ed.; Barnes, H.L., Ed.; Wiley Interscience: New York, NY, USA, 1979; pp. 278-403.

22. Heald, P.; Foley, N.K.; Hayba, D.O. Comparative anatomy of volcanic-hosted epithermal deposits; acid-sulfate and adularia-sericite types. Econ. Geol. 1987, 82, 1-26. [CrossRef]

23. Geological Survey of Japan, AIST. Geological map of Japan 1:2,000,000, 5th ed. In 1:2,000,000 Map Series, 4th ed.; Geological Survey of Japan: Tsukuba, Ibaraki, Japan, 2002.

24. Izawa, E.; Urashima, Y. Quaternary gold mineralization and its geologic environments in Kyushu, Japan. In Society of Economic Geologists Guidebook Series (CD-ROM); Society of Economic Geologists: Littletown, CO, USA, 2001; Volume 34, pp. 1-9.

25. Izawa, E.; Urashima, Y. Quaternary gold mineralization at its geologic environments in Kyushu, Japan. Econ. Geol. 1989, 6, 233-241.

26. Izawa, E. Evolution of volcanic and hydrothermal systems in southern Kyushu. Geol. Surv. Jpn. Rep. 1992, $279,84-88$.

27. Hedenquist, J.W.; Matsuhisa, Y.; Izawa, E.; White, N.C.; Giggenbach, W.F.; Aoki, M. Geology, geochemistry, and origin of high sulfidation Cu-Au mineralization in the Nansatsu District. Jpn. Econ. Geol. 1994, 89, 1-30. [CrossRef] 
28. Urashima, Y.; Izawa, E.; Hedenquist, J.W. Nansatsu-Type Gold Mineralization in the Makurazaki District. In Society of Mining Geologists of Japan Guidebook2; Mining Geologists of Japan: Akasaka, Tokyo, Japan, 1987; Volume 2, pp. 13-22.

29. Izawa, E.; Urashima, Y.; Ibaraki, K.; Suzuki, R.; Yokoyama, T.; Kawasaki, K.; Koga, A.; Taguchi, S. The Hishikari gold deposit: High-grade epithermal veins in Quaternary volcanics of southern Kyushu Jpn. J. Geochem. Explor. 1990, 36, 1-56. [CrossRef]

30. Hammond, N.Q.; Morishita, Y. Source of ore fluids at the Kalahari Goldridge deposit, Kraaipan greenstone belt, South Africa: Evidence from Sr, C and O isotope signatures in carbonates. Geofluids 2009, 9, 356-364. [CrossRef]

31. Tokunaga, M. Geology and ore deposits of the Kasuga mine and Akeshi mine, in the Makurazaki district, Kagoshima prefecture. Min. Geol. 1954, 4, 205-212, (In Japanese with English abstract).

32. Morishita, Y.; Nakano, T. Role of basement in epithermal deposits: The Kushikino and Hishikari gold deposits, southwestern Japan. Ore Geol. Rev. 2008, 34, 597-609. [CrossRef]

33. Hammond, N.Q.; Moore, J.M. Archaean lode gold mineralization in banded iron formation at the Kalahari Goldridge deposit, Kraaipan greenstone belt, South Africa. Miner. Depos. 2006, 41, 483-503. [CrossRef]

34. Hammond, N.Q.; Moore, J.M.; Sheets, R.W. Physico-chemical conditions of ore-forming fluids associated with genesis of the Kalahari Goldridge deposit, Kraaipan Greenstone Belt, South Africa. Ore Geol. Rev. 2007, 30, 106-134. [CrossRef]

35. Anhaeusser, C.R.; Walraven, F. Episodic granitoid emplacement in western Kaapvaal Craton: Evidence from the Achaean Kraaipan granite-greenstone terrane, South Africa. J. Afr. Earth Sci. 1999, 28, 289-309. [CrossRef]

36. Gold Fields Ltd. 2017 Mineral Resources and Mineral Reserves Supplement. 2017. Available online: https://www.goldfields.com/pdf/investors/integrated-annual-reports/2017/mrr-2017-hires.pdf (accessed on 19 April 2019).

37. Robb, L.J.; Robb, V.M. Gold in the Witwatersrand Basin. In The Mineral Resources of South Africa: Handbook; Wilson, M.G.C., Anhaeusser, C.R., Eds.; Council for Geoscience: Silverton, CO, USA, 1998; Volume 16, pp. 294-349.

38. Robb, L.J.; Meyer, F. The Witwatersrand Basin, South Africa: Geological framework and mineralization processes. Ore Geol. Rev. 1995, 10, 67-94. [CrossRef]

39. Gold Fields Ltd. Kloof-Driefontein Complex (KDC) Technical Short Form Report 31 December 2011. Available online: https://goldfields.com/reports/ar_dec_2011/minerals/pdf/kdc_mine.pdf (accessed on 19 April 2019).

40. Tucker, R.F.; Viljoen, R.P.; Viljoen, M.J. A Review of the Witwatersrand Basin-The World's Greatest Goldfield. Episodes 2016, 39, 105. [CrossRef]

41. Gold Fields Ltd. Gold Fields 2018 Results. Available online: http://www.goldfields.com/reports/fy2018/pdf/ booklet.pdf (accessed on 19 April 2019).

42. Sibanye-Stillwater Ltd. Company Financial Statements 2017. Available online: http://reports. sibanyestillwater.com/2017/download/SBY-CFS2017.pdf (accessed on 19 April 2019).

43. Sibanye-Stillwater Ltd. Operating and Financial Results for the six Months and Year Ended 31 December 2018. Available online: https://thevault.exchange/?get_group_doc=245/1550722223-sibanye-results-bookletH2-YE-2018-21feb2019.pdf (accessed on 19 April 2019).

44. Phillipps, G.N.; Law, J.D.M. Witwatersrand Gold Fields: Geology, Genesis, and Exploration. Rev. Econ. Geol. 2000, 13, 439-500.

45. MITI. Report on the Regional Survey of the Nansatsu Region, Heisei 11 (FY); Ministry of International Trade and Industry: Tokyo, Japan, 2000; p. 58. (In Japanese)

46. Pettijohn, F.J. Sedimentary Rocks, 3rd ed.; Harper \& Row: New York, NY, USA, 1975; pp. 56-61.

47. Tauson, V.L. Gold solubility in the common gold-bearing minerals: Experimental evaluation and application to pyrite. Eur. J. Miner. 1999, 11, 937-948. [CrossRef]

48. Simon, G.; Kao, L.S.; Huang, H.; Penner-Hahn, J.E.; Kesler, S.E. Oxidation state of gold and arsenic in gold-bearing arsenian pyrite. Am. Miner. 1999, 84, 1071-1079. [CrossRef] 
49. Groves, D.I.; England, G.L.; Rasmussen, B.; Krapež, B. Palaeoenvironmental significance of rounded pyrite in siliciclastic sequences of the Late Archaean Witwatersrand Basin: Oxygen-deficient atmosphere or hydrothermal alteration? Sedimentology. 2002, 49, 1133-1156.

50. Sung, Y.H.; Brugger, J.; Ciobanu, C.L.; Pring, A.; Skinner, W.; Nugus, M. Invisible gold in arsenian pyrite and arsenopyrite from a multistage Archaean gold deposit: Sunrise Dam, Eastern Gold fields Province, Western Australia. Min. Depos. 2009, 44, 765-791. [CrossRef]

(C) 2019 by the authors. Licensee MDPI, Basel, Switzerland. This article is an open access article distributed under the terms and conditions of the Creative Commons Attribution (CC BY) license (http://creativecommons.org/licenses/by/4.0/). 